\title{
Characterization of biomass burning emissions from cooking fires, peat, crop residue, and other fuels with high-resolution proton-transfer-reaction time-of-flight mass spectrometry
}

\author{
C. E. Stockwell ${ }^{1}$, P. R. Veres ${ }^{2,3}$, J. Williams ${ }^{4}$, and R. J. Yokelson ${ }^{1}$ \\ ${ }^{1}$ University of Montana, Department of Chemistry, Missoula, MT, USA \\ ${ }^{2}$ Cooperative Institute for Research in Environmental Sciences, University of Colorado, Boulder, CO, USA \\ ${ }^{3}$ Chemical Sciences Division, Earth System Research Laboratory, National Oceanic and \\ Atmospheric Administration, Boulder, CO, USA \\ ${ }^{4}$ Max Planck Institute for Chemistry, Atmospheric Chemistry Department, 55128 Mainz, Germany
}

Correspondence to: R. J. Yokelson (bob.yokelson@umontana.edu)

Received: 23 July 2014 - Published in Atmos. Chem. Phys. Discuss.: 29 August 2014

Revised: 9 December 2014 - Accepted: 9 December 2014 - Published: 23 January 2015

\begin{abstract}
We deployed a high-resolution proton-transferreaction time-of-flight mass spectrometer (PTR-TOF-MS) to measure biomass-burning emissions from peat, crop residue, cooking fires, and many other fire types during the fourth Fire Lab at Missoula Experiment (FLAME-4) laboratory campaign. A combination of gas standard calibrations and composition sensitive, mass-dependent calibration curves was applied to quantify gas-phase non-methane organic compounds (NMOCs) observed in the complex mixture of fire emissions. We used several approaches to assign the best identities to most major "exact masses", including many high molecular mass species. Using these methods, approximately $80-96 \%$ of the total NMOC mass detected by the PTR-TOFMS and Fourier transform infrared (FTIR) spectroscopy was positively or tentatively identified for major fuel types. We report data for many rarely measured or previously unmeasured emissions in several compound classes including aromatic hydrocarbons, phenolic compounds, and furans; many of these are suspected secondary organic aerosol precursors. A large set of new emission factors (EFs) for a range of globally significant biomass fuels is presented. Measurements show that oxygenated NMOCs accounted for the largest fraction of emissions of all compound classes. In a brief study of various traditional and advanced cooking methods, the EFs for these emissions groups were greatest for open threestone cooking in comparison to their more advanced counterparts. Several little-studied nitrogen-containing organic com-
\end{abstract}

pounds were detected from many fuel types, that together accounted for $0.1-8.7 \%$ of the fuel nitrogen, and some may play a role in new particle formation.

\section{Introduction}

Biomass burning (BB) injects large amounts of primary, fine carbonaceous particles and trace gases into the global atmosphere and significantly impacts its physical and chemical properties (Crutzen and Andreae, 1990; Bond et al., 2004, 2013). While BB emissions are recognized as the second largest global atmospheric source of gas-phase non-methane organic compounds (NMOCs) after biogenic emissions, a significant portion of the higher molecular weight species remains unidentified (Christian et al., 2003; Warneke et al., 2011; Yokelson et al., 2013). It is widely accepted that the addition of large amounts of these highly reactive species into the atmosphere alters chemistry on local to global scales (Andreae and Merlet, 2001; Andreae et al., 2001; Karl et al., 2007). NMOCs particularly impact smoke evolution by rapid formation of secondary organic aerosols (SOA) and secondary gases including photochemical ozone $\left(\mathrm{O}_{3}\right)$ (Reid et al., 1998; Trentmann et al., 2005; Alvarado and Prinn, 2009; Yokelson et al., 2009; Vakkari et al., 2014).

The many unknowns and initial gas-phase variability of BB emissions limit our ability to accurately model the atmo- 
spheric impacts of fire at all scales (Trentmann et al., 2005; Mason et al., 2006; Alvarado and Prinn, 2009; Alvarado et al., 2009; Wiedinmyer et al., 2011). Estimating or modeling the potential of smoke photochemistry to generate secondary aerosols or $\mathrm{O}_{3}$ requires realistic estimates of NMOC emissions in fresh smoke and knowledge of the chemical processing environment. Measurements capable of identifying and quantifying rarely measured and presently unidentified emissions of NMOCs, in particular the chemically complex low volatility fraction, are vital for advancing current understanding of the BB impact on air quality and climate.

Proton-transfer-reaction time-of-flight mass spectrometry (PTR-TOF-MS) is an emerging technique that simultaneously detects most NMOCs present in air samples, including oxygenated organics, aromatics, alkenes, and nitrogen (N)containing species at parts per trillion detection limits (pptv) (Jordan et al., 2009; Graus et al., 2010). The instrument uses $\mathrm{H}_{3} \mathrm{O}^{+}$reagent ions to ionize NMOCs via proton transfer reactions to obtain high-resolution mass spectra of protonated NMOCs with a low degree of molecular fragmentation at a mass accuracy sufficient enough to determine molecular formulas $\left(\mathrm{C}_{\mathrm{w}} \mathrm{H}_{\mathrm{x}} \mathrm{N}_{\mathrm{y}} \mathrm{O}_{\mathrm{z}}\right)$.

Although there are many advantages to PTR-TOF-MS over conventional PTR quadrupole mass spectrometers (increased mass range, high measurement frequency, and high mass resolution) there remain several difficulties involving PTR technology, including (1) detection being limited to molecules with a proton affinity greater than water, (2) complicated spectra due to parent ion fragmentation or cluster ion formation, and (3) the inability of the method to isolate isomers. Despite the limitations of this technology, PTR-TOFMS is ideal for studying complex gaseous mixtures such as those present in BB smoke.

This study was carried out as part of a large-scale experiment to characterize the initial properties and aging of gas- and particle-phase emissions in smoke from globally significant fuels. Experiments were conducted from October to November 2012 during the fourth Fire Lab at Missoula Experiment (FLAME-4) as detailed by Stockwell et al. (2014). A major goal of the study focused on the identification and quantification of highly reactive NMOCs in order to (1) better characterize the overall chemical and physical properties of fresh BB emissions; (2) better understand the distribution of emitted carbon across a range of volatilities in fresh and aged smoke; and (3) improve the capability of current photochemical models to simulate the climatic, radiative, chemical, and ecological impacts of smoke on local to global scales. In a companion paper, the FLAME-4 emissions were compared extensively to field measurements of fire emissions and were shown to be representative of "realworld" BB either as is or after straightforward adjustment procedures detailed therein (Stockwell et al., 2014). In this work, we describe the first application (to our knowledge) of PTR-TOF-MS technology to laboratory BB smoke to characterize emissions from a variety of authentic globally sig- nificant fuels. We report on several new or rarely measured gases and present a large set of useful emission ratios (ERs) and emission factors (EFs) for major fuel types that can inform/update current atmospheric models.

\section{Experimental details}

\subsection{Missoula fire sciences laboratory}

The US Forest Service Fire Sciences Laboratory (FSL) in Missoula, MT houses a large indoor combustion room described in detail elsewhere (Christian et al., 2003; Burling et al., 2010; Stockwell et al., 2014). In short, fuels are burned on a bed located directly below a $1.6 \mathrm{~m}$ diameter exhaust stack. The room is slightly pressurized by outdoor air that generates a large flow, entraining the fire emissions up through the stack. Emissions are drawn into sampling lines fixed in the stack at a platform height $17 \mathrm{~m}$ above the fuel bed. Past studies demonstrated that temperature and mixing ratios are constant across the width of the stack at the platform height, confirming well-mixed emissions (Christian et al., 2004).

Burns were conducted using two separate configurations as described in Stockwell et al. (2014). In this paper we will focus on 125 of the 157 burns. During these fires, wellmixed fresh smoke was sampled directly from the combustion stack by PTR-TOF-MS roughly $5 \mathrm{~s}$ after emission. Results obtained during the remaining burns that investigate photochemically processed smoke composition in dual smog chambers with a suite of state-of-the-art instrumentation are presented elsewhere (Tkacik et al., 2014).

\subsection{Biomass fuels}

Descriptions and ignition methods of each fuel type burned during FLAME-4 are detailed in Stockwell et al. (2014). Authentic globally significant fuels were collected, including African savanna grasses; US grasses; US and Asian crop residue; Indonesian, temperate, and boreal peat; temperate and boreal coniferous canopy fuels; woods in traditional and advanced cooking stoves; shredded tires; and trash. The range of fuel loading was chosen to simulate real-world conditions for the investigated fuel types with global examples of biomass consumption shown in Akagi et al. (2011).

\subsection{Proton-transfer-reaction time-of-flight mass spectrometer}

Real-time analysis of NMOCs was performed using a commercial PTR-TOF-MS 8000 instrument from Ionicon Analytik GmbH (Innsbruck, Austria) that is described in detail by Jordan et al. (2009). The PTR-TOF-MS sampled continuously at a frequency of $0.2 \mathrm{~Hz}$ through heated PEEK tubing $\left(0.0003 \mathrm{~m}\right.$ o.d., $\left.80^{\circ} \mathrm{C}\right)$ positioned facing upward to limit particulate uptake. The instrument was configured with a mass resolution $(\mathrm{m} / \Delta m)$ in the range of 4000 to 5000 at $\mathrm{m} / z 21$ 
and a typical mass range from $m / z 10$ to 600 . The drift tube was operated at $600 \mathrm{~V}$ with a pressure of $2.3 \mathrm{mbar}$ at $80^{\circ} \mathrm{C}$ $(E / N \sim 136 \mathrm{Td}$, with $E$ as the electric field strength and $N$ as the concentration of neutral gas; $1 \mathrm{Td}=10^{-17} \mathrm{~V} \mathrm{~cm}^{2}$ ). A dynamic dilution system was set up to reduce the concentration of sampled smoke and minimize reagent ion depletion. Mass calibration was performed by permeating 1,3diiodobenzene (protonated parent mass at $\mathrm{m} / \mathrm{z} 330.85$; fragments at $\mathrm{m} / z 203.94$ and 204.94) into a $1 \mathrm{~mm}$ section of Teflon tubing used in the inlet flow system. The high mass accuracy of the data allowed for the determination of the atomic composition of protonated NMOC signals where peaks were clearly resolved. The post-acquisition data analysis to retrieve counts per second based on peak analysis was performed according to procedures described in detail elsewhere (Müller et al., 2013, 2011, 2010). An initial selection of ions ( $\sim 68$ masses up to $m / z \sim 143$ ) was chosen based upon incidence and abundance for post-acquisition analysis. In select cases (nominally one fire of each fuel type), additional compounds $(\sim 50$ masses $)$ were analyzed and are reported separately within this paper. A reasonable estimation procedure showed that the peaks selected for analysis accounted for $>99 \%$ of the NMOC mass up to $m / z 165$ in our PTRTOF-MS spectra. An earlier BB study (Yokelson et al., 2013) using mass scans to $m / z 214$ found that $\sim 1.5 \%$ of NMOC mass was present at $m / z>165$.

Calibration of the PTR-TOF-MS was performed every few days at the FSL using a bottle gas standard (Apel-Riemer Environmental). Calibrations were performed by adding a known quantity of calibration gas directly to the end of the PTR-TOF-MS sample inlet. The calibration mixture included formaldehyde $(\mathrm{HCHO})$, methanol $\left(\mathrm{CH}_{3} \mathrm{OH}\right)$, acetonitrile $\left(\mathrm{CH}_{3} \mathrm{CN}\right)$, acetaldehyde $\left(\mathrm{CH}_{3} \mathrm{CHO}\right)$, acetone $\left(\mathrm{C}_{3} \mathrm{H}_{6} \mathrm{O}\right)$, dimethyl sulfide $\left(\mathrm{C}_{2} \mathrm{H}_{6} \mathrm{~S}\right)$, isoprene $\left(\mathrm{C}_{5} \mathrm{H}_{8}\right)$, methyl vinyl ketone $\left(\mathrm{C}_{4} \mathrm{H}_{6} \mathrm{O}\right)$, methyl ethyl ketone $\left(\mathrm{C}_{4} \mathrm{H}_{8} \mathrm{O}\right)$, benzene $\left(\mathrm{C}_{6} \mathrm{H}_{6}\right)$, toluene $\left(\mathrm{C}_{6} \mathrm{H}_{5} \mathrm{CH}_{3}\right)$, p-xylene $\left(\mathrm{C}_{8} \mathrm{H}_{10}\right), 1,3,5-$ trimethylbenzene $\left(\mathrm{C}_{9} \mathrm{H}_{12}\right)$, and $\alpha$-pinene $\left(\mathrm{C}_{10} \mathrm{H}_{16}\right)$.

The normalized sensitivity of the instrument (ncps ppbv ${ }^{-1}$ ) was determined for calibrated compounds based on the slope of the linear fit of signal intensities (normalized to the $\mathrm{H}_{3} \mathrm{O}^{+}$signal, $\sim 10^{6} \mathrm{cps}$ ) versus a range of volumetric mixing ratios (VMR). Multipoint calibration curves varied due to instrumental drift and dilution adjustments accordingly, and average calibration factors (CFs, ncps ppbv ${ }^{-1}$ ) were determined throughout the field campaign as described by Warneke et al. (2011) and were used to calculate concentrations.

Quantification of the remaining species was performed using calculated mass-dependent calibration factors based on the measured calibration factors. Figure 1a shows the spread in the normalized response of compounds versus mass (labeled by compound name) overlaid with the linearly fitted mass-dependent transmission curve (black markers and dotted line). It is clear from Fig. 1a that the oxygenated species (blue labels) and the hydrocarbon species (green labels) ex- hibit a slightly different mass-dependent behavior; however, both groups show a linear increase with mass that is similar to that observed for the transmission efficiency (Fig. 1b and c). To reduce bias, mass-dependent calibration factors were determined using a linear approximation for oxygenated and hydrocarbon species separately (Fig. $1 \mathrm{~b}$ and c). $\alpha$-Pinene was not included in the linear approximation for hydrocarbons as this compound is well known to be susceptible to substantial fragmentation in the drift tube. Sulfur (S)- and N-containing compounds were considered collectively, and together they more closely follow the trend of the oxygenated species. Thus, in cases where a compound contains a non-oxygen heteroatom (such as methanethiol), the mass-dependent calibration factor was determined using the relationship established using the oxygenated species. Calibration factors were then determined according to the exact mass for all peaks where the chemical formula has been determined. Our approach does not yet account for the potential for ions to fragment and/or cluster; however, we expect this impacts less than $30 \%$ of NMOC and usually to a small degree for any individual species. These latter issues change the mass distribution of observed carbon but should not have a large effect on the total observed carbon.

It is difficult to assess the overall error introduced using this method of calibration factor approximation, as only a limited number of comparable measurements of calibration factors are available. The deviation of measured calibration factors for species contained in the gas standard from the linear approximation yields a range of errors $(21 \pm 19 \%)$ with a maximum of $50 \%$ observed in all cases (excluding $\alpha$-pinene for reasons detailed above). While PTR-TOF-MS is typically known as a soft ionization method, fragmentation is common among higher molecular weight species and therefore needs to be considered as a limitation of this technique. For the individual species identified it would be misleading to give a set error based on this limited analysis; however, in the absence of any known molecular fragmentation, a maximum error of $50 \%$ is prescribed although larger errors are possible for compounds with $\mathrm{N}$ and $\mathrm{S}$ heteroatoms. Better methods for the calculation of mass-dependent calibration factors by compound class should be developed in the near future to improve the accuracy of volatile organic compound (VOC) measurements using PTR-TOF-MS.

\subsection{OP-FTIR}

To enhance application of the MS data, emission ratios to carbon monoxide $(\mathrm{CO})$ were calculated where possible using measurements from an open-path Fourier transform infrared (OP-FTIR) spectrometer described elsewhere (Stockwell et al., 2014). The system includes a Bruker Matrix-M IR cube spectrometer with an open White cell that was positioned to span the width of the stack to sample the continuously rising emissions. The spectral resolution was set to $0.67 \mathrm{~cm}^{-1}$ and spectra were collected every $1.5 \mathrm{~s}$ with a duty cycle 

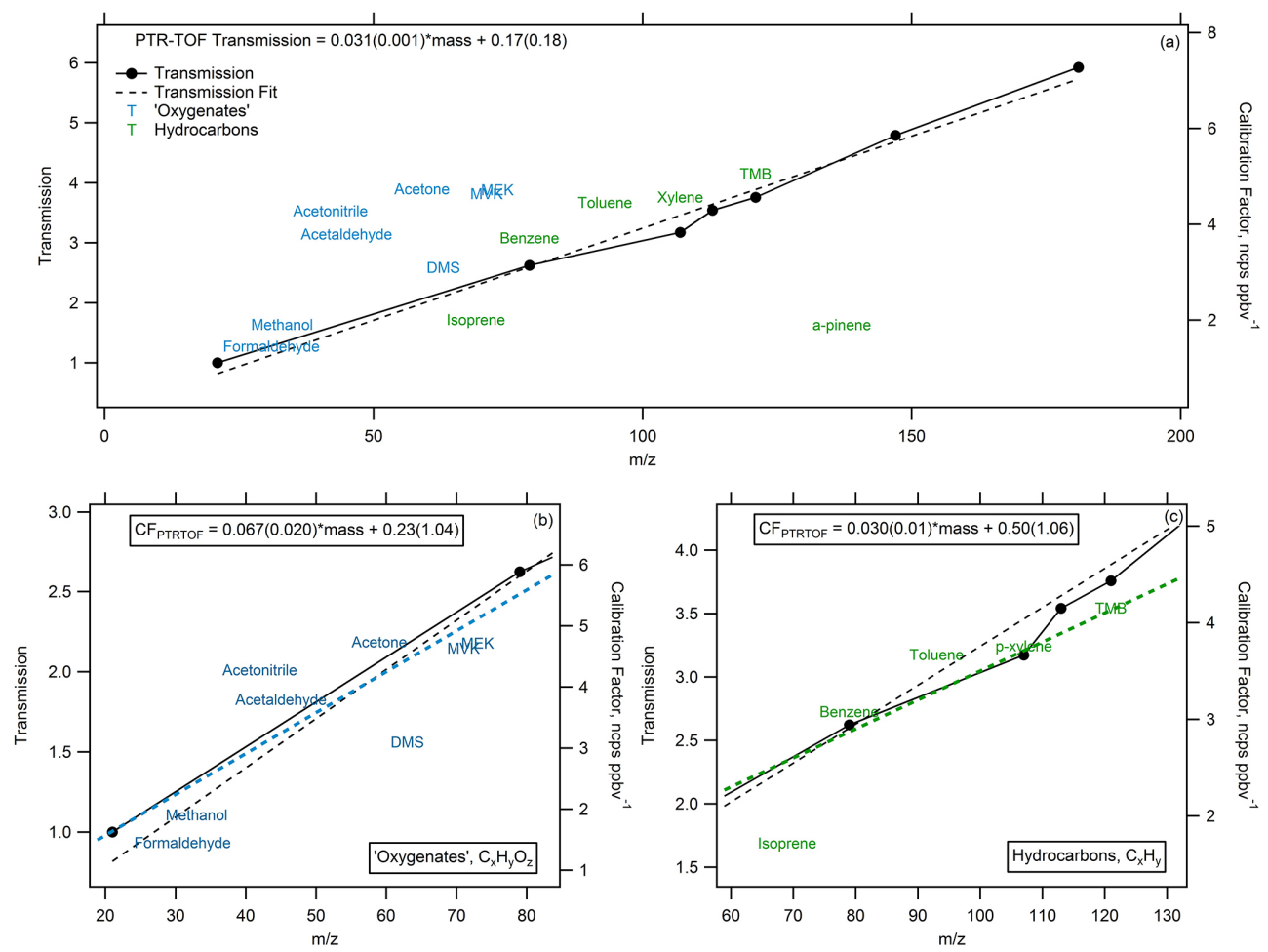

Figure 1. (a) The normalized response of calibration factors ("CF," ncps ppbv ${ }^{-1}$ ) versus mass (calibrated species labeled by name) overlaid with the linearly fitted mass-dependent transmission curve (black markers and dotted line). Separate linear approximations of (b) oxygenated (blue) and (c) hydrocarbon (green) species used to calculate approximate calibration factors for all observed masses where explicit calibrations were not available.

greater than $95 \%$. Other gas-phase species quantified by this method included carbon dioxide $\left(\mathrm{CO}_{2}\right)$, methane $\left(\mathrm{CH}_{4}\right)$, ethyne $\left(\mathrm{C}_{2} \mathrm{H}_{2}\right)$, ethene $\left(\mathrm{C}_{2} \mathrm{H}_{4}\right)$, propylene $\left(\mathrm{C}_{3} \mathrm{H}_{6}\right)$, formaldehyde $(\mathrm{HCHO})$, formic acid $(\mathrm{HCOOH})$, methanol $\left(\mathrm{CH}_{3} \mathrm{OH}\right)$, acetic acid $\left(\mathrm{CH}_{3} \mathrm{COOH}\right)$, glycolaldehyde $\left(\mathrm{C}_{2} \mathrm{H}_{4} \mathrm{O}_{2}\right)$, furan $\left(\mathrm{C}_{4} \mathrm{H}_{4} \mathrm{O}\right)$, water $\left(\mathrm{H}_{2} \mathrm{O}\right)$, nitric oxide $(\mathrm{NO})$, nitrogen dioxide $\left(\mathrm{NO}_{2}\right)$, nitrous acid $(\mathrm{HONO})$, ammonia $\left(\mathrm{NH}_{3}\right)$, hydrogen cyanide $(\mathrm{HCN})$, hydrogen chloride $(\mathrm{HCl})$, and sulfur dioxide $\left(\mathrm{SO}_{2}\right)$ and were obtained by multi-component fits to selected regions of the mid-IR transmission spectra with a synthetic calibration non-linear least-squares method (Griffith, 1996; Yokelson et al., 2007).

The OP-FTIR system had the highest time resolution with no sampling line, storage, fragmentation, or clustering artifacts; thus, for species in common with PTR-TOF-MS, the OP-FTIR data was used as the primary data. The results from the intercomparison (for methanol) of OP-FTIR and PTRTOF-MS show excellent agreement using an orthogonal distance regression to determine slope $(0.995 \pm 0.008)$ and the $\mathrm{R}^{2}$ coefficient $(0.789)$. This result is consistent with the good agreement for several species measured by both PTR-MS and OP-FTIR observed in numerous past studies of laboratory BB emissions (Christian et al., 2004; Karl et al., 2007; Veres et al. 2010; Warneke et al., 2011).

\subsection{Emission ratio and emission factor determination}

Excess mixing ratios (denoted $\Delta \mathrm{X}$ for each species "X") were calculated by applying an interpolated background correction (determined from the pre- and post-fire concentrations). The molar emission ratio (ER) for each species " $\mathrm{X}$ " relative to $\mathrm{CH}_{3} \mathrm{OH}\left(\Delta \mathrm{X} / \Delta \mathrm{CH}_{3} \mathrm{OH}\right)$ is the ratio between the integral of $\Delta \mathrm{X}$ over the entire fire and the integral of $\Delta \mathrm{CH}_{3} \mathrm{OH}$ over the entire fire. We selected $\mathrm{CH}_{3} \mathrm{OH}$ as the species in common with the OP-FTIR to serve as an internal standard for the calculation of the fire-integrated ERs of each species X to CO (Supplement Table S1). We do this by multiplying the MS-derived ER $\left(\Delta \mathrm{X} / \Delta \mathrm{CH}_{3} \mathrm{OH}\right)$ by the FTIR-derived ER $\left(\Delta \mathrm{CH}_{3} \mathrm{OH} / \Delta \mathrm{CO}\right)$, which minimizes error due to occasional reagent ion depletion or the different sampling frequencies between instruments that would impact calculating $\Delta \mathrm{X}$ to $\Delta \mathrm{CO}$ directly. Several fires have been excluded from this calculation as data were either not collected by OP-FTIR and/or PTR-TOF-MS or, alternatively, methanol data could not be applied for the conversion because (1) the mixing ratios remained below the detection limit or (2) methanol was used to assist ignition purposes during a few fires. In the case of the tire fires only, the latter issue with $\mathrm{CH}_{3} \mathrm{OH}$ was circumvented by using $\mathrm{HCOOH}$ $(m / z 47)$ as a suitable, alternative internal standard. As dis- 
cussed in Sect. 2.3., $\sim 50$ additional masses were analyzed for selected fires and the ERs (to CO) for these fires are included in the bottom panels of Table S1. The combined ERs to CO from the FTIR and PTR-TOF were then used to calculate emission factors (EFs, $\mathrm{g} \mathrm{kg}^{-1}$ dry biomass burned) by the carbon mass-balance method (CMB) based on the assumption that all of the burned carbon is volatilized and that all of the major carbon-containing species have been measured (Ward and Radke, 1993; Yokelson et al., 1996, 1999; Burling et al., 2010). EFs were previously calculated solely from FLAME-4 OP-FTIR data as described in Stockwell et al. (2014), and a new larger set of EFs, which includes more carbon-containing species quantified by PTRTOF-MS, is now shown in Supplement Table S2. With the additional carbon compounds quantified by PTR-TOF-MS, the EFs calculated by CMB decreased $\sim 1-2 \%$ for most major fuels with respect to the previous EFs reported in Stockwell et al. (2014). In the case of peat and sugar cane fires, the OP-FTIR-derived EFs are now reduced by a range of $\sim 2$ $5 \%$ and $3.5-7.5 \%$, respectively. Along with these small reductions, this work now provides EFs for many additional species that were unavailable in Stockwell et al. (2014). Finally, the EFs reported in Supplement Table S3 were adjusted (when needed) according to procedures established in Stockwell et al. (2014) to improve laboratory representation of real-world BB emissions. This table contains the EF we recommend other workers use and it appears in the Supplement only because of its large size. In addition to the comparisons considered in Stockwell et al. (2014), we find that our EFs in Table S3 are consistent (for the limited number of overlap species) with additional, recent field studies including Kudo et al. (2014) for Chinese crop residue fires and Geron and Hays (2013) for North Carolina (NC) peat fires.

Fire emissions are partially dependent on naturally changing combustion processes. To estimate the relative amount of smoldering and flaming combustion that occurred over the course of each fire, the modified combustion efficiency (MCE) is calculated by (Yokelson et al., 1996)

$\mathrm{MCE}=\frac{\Delta \mathrm{CO}_{2}}{\Delta \mathrm{CO}_{2}+\Delta \mathrm{CO}}=\frac{1}{\left(1+\left(\frac{\Delta \mathrm{CO}}{\Delta \mathrm{CO}_{2}}\right)\right)}$.

Though flaming and smoldering combustion often occur simultaneously, a higher MCE value (approaching 0.99) designates relatively pure flaming combustion (more complete oxidation), a lower MCE (0.75-0.84) designates pure smoldering combustion, and thus an MCE of $\sim 0.9$ represents roughly equal amounts of flaming and smoldering. Each fireintegrated MCE is reported in Tables S1-S3.
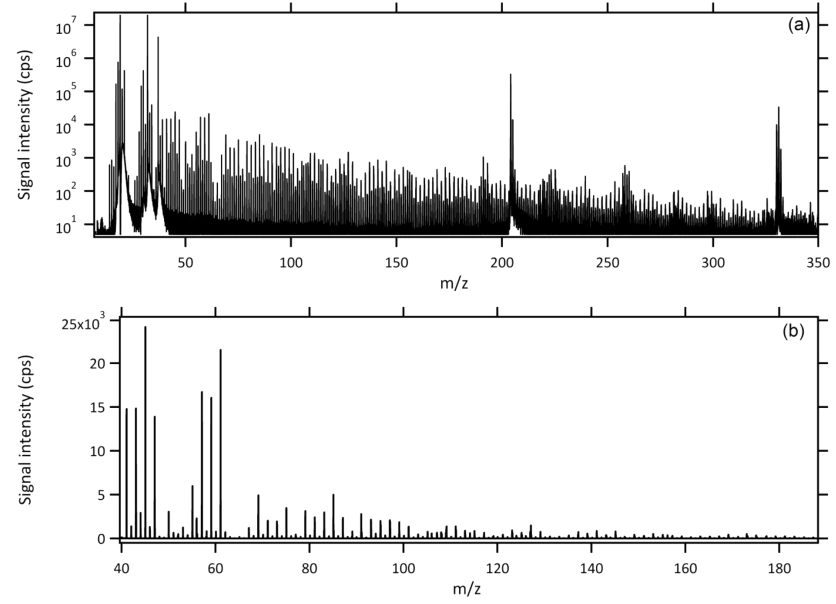

Figure 2. A typical full mass scan of biomass burning smoke from the PTR-TOF-MS on a logarithmic (a) and a smaller range linear (b) scale. The internal standard (1,3-diiodobenzene) accounts for the major peaks $\sim m / z, 331$ and fragments at peaks near $m / z 204$ and 205.

\section{Results}

\subsection{Peak assignment}

As exemplified by a typical PTR-TOF-MS spectrum of diluted smoke (Fig. 2a), the complexity of BB smoke emissions presents challenges to mass spectral interpretation and ultimately emissions characterization. Figure $2 b$ shows a smaller mass range of the smoke sample shown in Fig. 2a on a linear scale to illustrate the typical relative importance of the masses (note the intensity of acetaldehyde $(\mathrm{m} / \mathrm{z} 45)$ and acetic acid plus glycolaldehyde $(\mathrm{m} / \mathrm{z} 61)$, which together account for almost $25 \%$ of the total signal). Although the spectra are very complex, systematic treatment of the burn data, assisted at some $m / z$ by extensive published "off-line" analyses, can generate reasonable assignments for many major peaks and result in useful emissions quantification.

As described earlier, the PTR-TOF-MS scans have sufficiently high resolution to assign molecular formulas $\left(\mathrm{C}_{\mathrm{w}} \mathrm{H}_{\mathrm{x}} \mathrm{N}_{\mathrm{y}} \mathrm{O}_{\mathrm{z}}\right)$ to specific ion peaks by matching the measured exact mass with possible formula candidates for the protonated compound. Specific compound identification for formula candidates can be unambiguous if only one species is structurally plausible or explicit identification of the compound had previously been confirmed by BB smoke analysis (Akagi et al., 2011; Yokelson et al., 2013, etc.). Supplement Table S4 lists every mass and formula assignment for observable peaks up to $m / z 165$ and categorizes each mass as a confirmed identity, a tentative (most likely) species assignment, or an unknown compound. For several confirmed identities, the most abundant species at that exact mass is listed with likely contributions to the total signal from the secondary species listed in column 5. Most of the tentatively 
identified species have, to our knowledge, typically not been directly observed in BB smoke but have been frequently verified as major products with off-line techniques in the extensive literature describing biomass pyrolysis experiments of various fuel types (Liu et al., 2012; Pittman Jr. et al., 2012; Li et al., 2013; more citations in Table S4). Several tentative assignments are supported by off-line analyses being published elsewhere (Hatch et al., 2014); for example, simultaneous grab samples analyzed by two-dimensional gas chromatography (2D-GC) support tentative assignments for furan methanol, salicylaldehyde, and benzofuran. In the case of $\mathrm{N}$-containing formulas, the suggested compounds have been observed in the atmosphere, tobacco smoke, or lab fire smoke at moderate levels (Lobert, 1991; Ge et al., 2011; etc). Select studies supporting these assignments are referenced in the mass table with alternative possibilities also listed. An exhaustive list of all the many papers supporting the assignments is beyond the scope of this work. Several remaining compounds are also classified as tentative assignments as the identities designated are thought to be the most structurally likely. We anticipate that some or even many of the tentative assignments (and a few of the confirmed assignments) will be refined in future years as a result of more studies becoming available. We offer the tentative assignments here as a realistic starting point that improves model input compared to an approach in which these species are simply ignored.

\subsection{Unidentified compounds}

The identities of several compounds remain unknown, especially at increasing mass where numerous structural and functional combinations are feasible. However, compared to earlier work at unit mass resolution (Warneke et al., 2011; Yokelson et al., 2013), the high-resolution capability of the PTR-TOF-MS has enhanced our ability to assign mass peaks while always identifying atomic composition. With unit mass resolution spectrometers, FTIR, and GC-MS grab samples, Yokelson et al. (2013) estimated that $\sim 31$ to $72 \%$ of the gasphase NMOC mass remained unidentified for several fuel types. For similar, commonly burned biomass fuels (chaparral, grasses, crop residue, etc.), considering a PTR-TOF range up to $m / z 165$, we estimate that $\sim 7 \%$ of the detected NMOC mass remains unidentified, while $\sim 12 \%$ is tentatively assigned using selection criteria described in Sect. 3.1. The compounds considered in this study cover a smaller mass range (up to $m / z 165$ rather than $m / z$ 214) than in the earlier study, but in that earlier study the compounds in the range $m / z \quad 165-214$ accounted for only $\sim 1.5 \%$ of the NMOC mass (Yokelson et al., 2013). Thus, the molecular formula assignments from the PTR-TOF aided in positive and tentative identification and quantification resulting in a reduction of the estimate of unidentified NMOCs from $\sim 31 \%$ down to $\sim 7 \%$.

Calculations of unidentified and tentatively assigned emissions relative to overall NMOC emissions (including FTIR species) for several lumped fuel groups are summarized in Table 1. Estimates of total intermediate and semivolatile gasphase organic compounds (IVOC + SVOC, estimated as the sum of species at or above the mass of toluene) are also included as these less volatile compounds are likely to generate SOA via oxidation and/or cooling. Similar to previous organic soil fire data, the percentages of unidentified and tentatively identified NMOCs for peat burns are significantly larger than for other fuel types (sum $\sim 37 \%$ ), and they could be a major source of impacts and uncertainty during El Niño years when peat combustion is a major global emission source (Page et al., 2002; Akagi et al., 2011).

\section{Discussion}

For all fuel types, there is noticeable variability concerning which compounds have the most significant emissions. Figure 3 includes both FTIR and PTR emissions grouped into the following categories: non-methane hydrocarbons, oxygenates containing only one oxygen, oxygenates containing two oxygen atoms, and oxygenates containing three oxygen atoms. Within these categories, the contributions from aromatics, phenolic compounds, and furans are further indicated. As shown in Fig. 3, oxygenated compounds account for the majority of the emissions for all biomass or biomass-containing fuels (i.e. tires and plastic bags are excluded). Oxygenated compounds containing only a single oxygen atom accounted for $\sim 50 \%$ of the total raw mass signal ( $>m / z 28$, excluding $m / z$ 37) on average and normally had greater emissions than oxygenated compounds containing two oxygen atoms or hydrocarbons. Sugar cane has the highest emissions of oxygenated compounds, as was noted earlier in the FTIR data (Stockwell et al., 2014), and is one of the few fuels where the emissions of compounds containing two oxygens are the largest. To facilitate discussion we grouped many of the assigned (or tentatively assigned) mass peak features into categories including aromatic hydrocarbons, phenolic compounds, furans, $\mathrm{N}$-containing compounds, and S-containing compounds. These categories do not account for the majority of the emitted NMOC mass but do account for most of the rarely measured species reported in this work. We then also discuss miscellaneous compounds at increasing $m / z$.

\subsection{Aromatic hydrocarbons}

Aromatic hydrocarbons contributed most significantly to the emissions for several major fuel types including ponderosa pine, peat, and black spruce. The identities of these ringed structures are more confidently assigned due to the small $\mathrm{H}$ to $\mathrm{C}$ ratio at high masses. The aromatics confidently identified in this study include benzene $(m / z$ 79), toluene $(m / z 93)$, phenylacetylene $(m / z ~ 103)$, styrene $(m / z 105)$, xylenes/ethylbenzene $(m / z, 107), 1,3,5-$ 
Table 1. Quantities for various categories of compounds $\left(\mathrm{g} \mathrm{kg}^{-1}\right)$ and calculation of mass ratios and/or percentages for several fuel types.

\begin{tabular}{lrrrrrrr}
\hline Quantity or ratio & Chaparral & $\begin{array}{r}\text { Coniferous } \\
\text { canopy }\end{array}$ & Peat & Grasses & $\begin{array}{r}\text { Cooking } \\
\text { fires }\end{array}$ & $\begin{array}{r}\text { Crop } \\
\text { residue }\end{array}$ & Trash \\
\hline$\Sigma$ NMOCs & 13.1 & 23.9 & 40.5 & 5.17 & 8.16 & 29.6 & 7.13 \\
$\Sigma$ I/SVOCs* & 3.49 & 7.13 & 14.6 & 1.38 & 1.33 & 7.21 & 1.83 \\
$\Sigma$ tentatively assigned NMOCs & 1.43 & 2.77 & 7.01 & 0.72 & 0.72 & 4.38 & 0.51 \\
$\Sigma$ unidentified NMOCs & 1.23 & 1.79 & 7.50 & 0.39 & 0.33 & 2.10 & 0.41 \\
$\Sigma$ (I/SVOCs)/ $\Sigma$ NMOC & 0.21 & 0.28 & 0.37 & 0.26 & 0.15 & 0.24 & 0.26 \\
Percent NMOCs tentatively assigned & 8.35 & 9.74 & 17.5 & 13.9 & 8.19 & 14.0 & 7.20 \\
Percent NMOCs unidentified & 7.24 & 6.75 & 19.5 & 7.19 & 3.77 & 6.90 & 5.75 \\
Percent NMOCs tentatively + unidentified & 16 & 16 & 37 & 21 & 12 & 21 & 13 \\
\hline
\end{tabular}

* See Sect. 3.2 for definition.

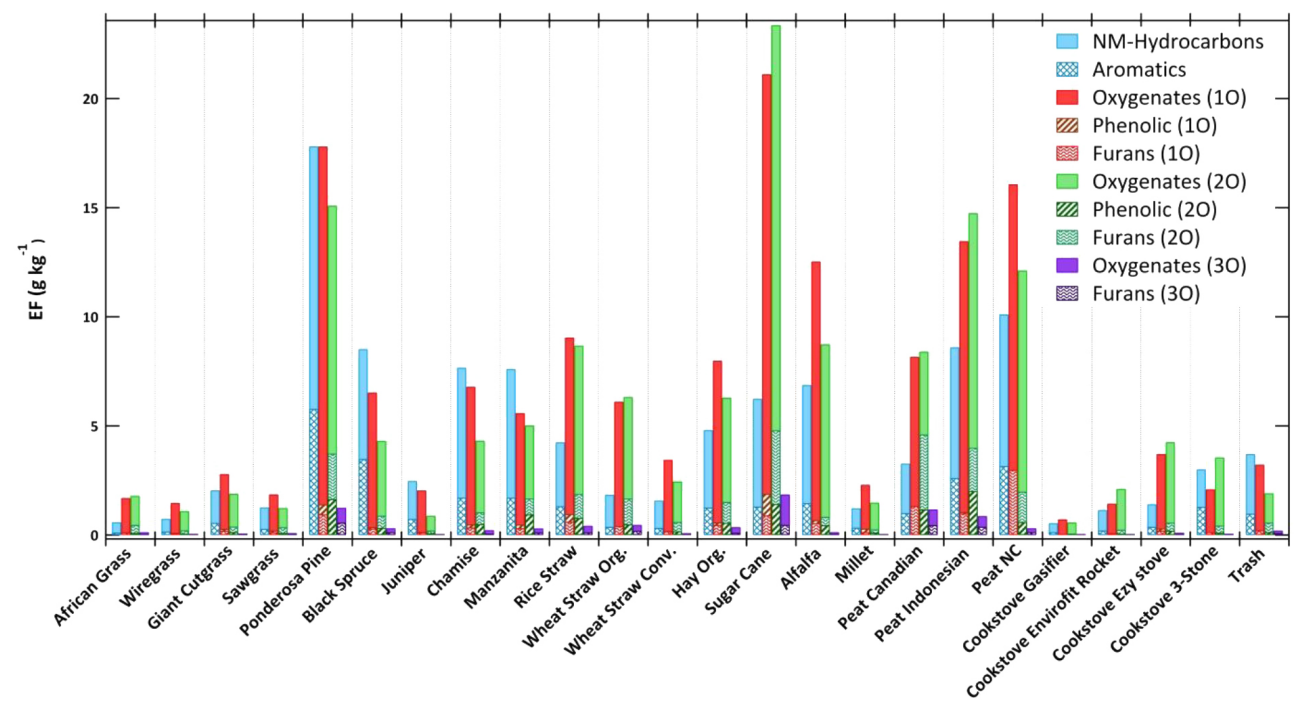

Figure 3. The emission factors $\left(\mathrm{g} \mathrm{kg}^{-1}\right)$ of total observed hydrocarbons and total observed species oxygenated to different degrees averaged for each fire type based on a synthesis of PTR-TOF-MS and OP-FTIR data. The patterned sections indicate the contribution to each of the above categories by selected functionalities discussed in the text (aromatic hydrocarbons, phenolics, furans). The parenthetical expressions indicate how many oxygen atoms are present.

trimethylbenzene $(\mathrm{m} / \mathrm{z} 121)$, and naphthalene $(\mathrm{m} / \mathrm{z} 129)$, while masses more tentatively assigned include dihydronaphthalene $(m / z 131), p$-cymene $(m / z 135)$, and methylnaphthalenes $(m / z 143)$. All masses are likely to have minor contributions from other hydrocarbon species. The EFs for aromatic species quantified during all fires are averaged by fuel type and shown in Fig. 4a. The EF for $p$-cymene was only calculated for select burns and has been included in Fig. 4a for comprehensiveness.

Aromatic structures are susceptible to multiple oxidation pathways and readily drive complex chemical reactions in the atmosphere that are highly dependent on hydroxyl radical $(\mathrm{OH})$ reactivity (Phousongphouang and Arey, 2002; Ziemann and Atkinson, 2012). Ultimately these gas-phase aromatic species have high yields for SOA as their physical and chemical evolution lead to lower volatility species that condense into the particle phase. SOA yields from these par- ent aromatic HCs have been shown to strongly vary depending on environmental parameters including relative humidity, temperature, aerosol mass concentration, and particularly the level of nitrogen oxides $\left(\mathrm{NO}_{\mathrm{x}}\right)$ and availability of $\mathrm{RO}_{2}$ radicals, further adding to the complexity in modeling the behavior and fate of these compounds (Ng et al., 2007; Song et al., 2007; Henze et al., 2008; Chhabra et al., 2010, 2011; Im et al., 2014).

Domestic biofuel burning and open BB together comprise the largest global atmospheric source of benzene (Andreae and Merlet, 2001; Henze et al., 2008); thus, not surprisingly, benzene is a significant aromatic in our data set. The ERs relative to benzene for the aromatics listed above are shown in Table 2 and are positively correlated with benzene as demonstrated by Fig. 4b. Henze et al. (2008) outline how ERs to $\mathrm{CO}$ of major aromatics (benzene, xylene, and toluene) can be implemented as a part of a model to predict SOA forma- 
Table 2a. Emission ratios to benzene, phenol, and furan for aromatic hydrocarbons, phenolic compounds, and substituted furans in lumped fuel categories.

\begin{tabular}{|c|c|c|c|c|c|c|}
\hline & $\begin{array}{l}\text { Fuel } \\
\text { type } \\
\text { (\# burns) }\end{array}$ & $\begin{array}{r}\text { Grasses } \\
(42)\end{array}$ & $\begin{array}{r}\text { Coniferous } \\
\text { canopy } \\
(14)\end{array}$ & $\begin{array}{r}\text { Chaparral } \\
(8)\end{array}$ & Peat (6) & $\begin{array}{r}\text { Crop } \\
\text { residue } \\
(\text { food, 19) }\end{array}$ \\
\hline ER/benzene & MCE & $0.968(0.010)$ & $0.933(0.032)$ & $0.927(0.017)$ & $0.767(0.074)$ & $0.946(0.022)$ \\
\hline Toluene & $\mathrm{C}_{7} \mathrm{H}_{8}$ & $0.44(0.26)$ & $2.19(0.84)$ & $0.49(0.17)$ & $0.53(0.17)$ & $0.70(0.22)$ \\
\hline Phenylacetylene & $\mathrm{C}_{8} \mathrm{H}_{6}$ & $0.094(0.022)$ & 0.13 & 0.067 (0.039) & - & $0.65(0.45)$ \\
\hline Styrene & $\mathrm{C}_{8} \mathrm{H}_{8}$ & $0.078(0.025)$ & $0.11(0.02)$ & $0.074(0.020)$ & $0.087(0.027)$ & $0.10(0.03)$ \\
\hline Xylenes/ethylbenzene & $\mathrm{C}_{8} \mathrm{H}_{10}$ & $0.102(0.058)$ & $0.21(0.03)$ & $0.12(0.03)$ & $0.32(0.16)$ & $0.20(0.08)$ \\
\hline Trimethylbenzene & $\mathrm{C}_{9} \mathrm{H}_{12}$ & $0.059(0.045)$ & $0.11(0.03)$ & $0.043(0.023)$ & $0.17(0.08)$ & $0.11(0.05)$ \\
\hline Naphthalene & $\mathrm{C}_{10} \mathrm{H}_{8}$ & $0.18(0.16)$ & $0.13(0.05)$ & $0.10(0.03)$ & $0.15(0.09)$ & $0.20(0.17)$ \\
\hline Dihydronaphthalene & $\mathrm{C}_{10} \mathrm{H}_{10}$ & $0.040(0.030)$ & $0.034(0.016)$ & $0.020(0.010)$ & $0.050(0.019)$ & $0.059(0.028)$ \\
\hline$p$-Cymene ${ }^{\mathrm{a}}$ & $\mathrm{C}_{10} \mathrm{H}_{14}$ & $0.018(0.013)$ & $0.11(0.01)$ & 0.037 & $0.15(0.12)$ & $0.035(0.019)$ \\
\hline Methylnaphthalenes & $\mathrm{C}_{11} \mathrm{H}_{10}$ & $0.032(0.009)$ & $0.053(0.005)$ & $0.033(0.007)$ & - & $0.19(0.09)$ \\
\hline \multicolumn{7}{|l|}{ ER/phenol } \\
\hline Cresols (methylphenols) ${ }^{\mathrm{a}}$ & $\mathrm{C}_{7} \mathrm{H}_{8} \mathrm{O}$ & $0.52(0.19)$ & $0.55(0.07)$ & 0.49 & $0.29(0.18)$ & $0.57(0.10)$ \\
\hline Catechol (benzenediols) ${ }^{\mathrm{b}}$ & $\mathrm{C}_{6} \mathrm{H}_{6} \mathrm{O}_{2}$ & $0.73(0.41)$ & $0.76(0.29)$ & $1.72(1.28)$ & $1.58(1.03)$ & $0.93(0.45)$ \\
\hline Vinylphenol & $\mathrm{C}_{8} \mathrm{H}_{8} \mathrm{O}$ & $0.66(0.19)$ & $0.33(0.09)$ & $0.30(0.05)$ & $0.18(0.05)$ & $0.60(0.35)$ \\
\hline Salicylaldehyde & $\mathrm{C}_{7} \mathrm{H}_{6} \mathrm{O}_{2}$ & $0.18(0.06)$ & $0.17(0.04)$ & $0.15(0.04)$ & $0.20(0.13)$ & $0.18(0.08)$ \\
\hline Xylenol (2,5-dimethyl phenol) & $\mathrm{C}_{8} \mathrm{H}_{10} \mathrm{O}$ & $0.25(0.09)$ & $0.19(0.06)$ & $0.11(0.06)$ & $0.31(0.09)$ & $0.34(0.07)$ \\
\hline Guaiacol (2-methoxyphenol) & $\mathrm{C}_{7} \mathrm{H}_{8} \mathrm{O}_{2}$ & $0.40(0.23)$ & $0.42(0.12)$ & $0.21(0.09)$ & $0.71(0.36)$ & $0.76(0.33)$ \\
\hline Creosol (4-methylguaiacol) ${ }^{\mathrm{a}}$ & $\mathrm{C}_{8} \mathrm{H}_{10} \mathrm{O}_{2}$ & $0.21(0.16)$ & $0.21(0.09)$ & 0.067 & $0.12(0.17)$ & $0.19(0.10)$ \\
\hline 3-Methoxycatechol ${ }^{\mathrm{a}}$ & $\mathrm{C}_{7} \mathrm{H}_{8} \mathrm{O}_{3}$ & $0.090(0.072)$ & $0.067(0.031)$ & 0.028 & $0.19(0.04)$ & $0.066(0.037)$ \\
\hline 4-Vinylguaiacol ${ }^{\mathrm{a}}$ & $\mathrm{C}_{9} \mathrm{H}_{10} \mathrm{O}_{2}$ & $0.29(0.19)$ & $0.27(0.12)$ & 0.052 & $0.27(0.04)$ & $0.37(0.19)$ \\
\hline Syringol $^{\mathrm{a}}$ & $\mathrm{C}_{8} \mathrm{H}_{10} \mathrm{O}_{3}$ & $0.13(0.07)$ & $0.078(0.029)$ & $0.21(0.12)$ & $0.22(0.07)$ & $0.16(0.10)$ \\
\hline \multicolumn{7}{|l|}{ ER/furan } \\
\hline 2-Methylfuran & $\mathrm{C}_{5} \mathrm{H}_{6} \mathrm{O}$ & $0.53(0.27)$ & $1.02(0.40)$ & $0.77(0.30)$ & $0.34(0.14)$ & $1.50(0.66)$ \\
\hline 2-Furanone & $\mathrm{C}_{4} \mathrm{H}_{4} \mathrm{O}_{2}$ & $0.93(0.50)$ & $1.53(0.80)$ & $0.96(0.49)$ & $0.44(0.36)$ & $2.05(1.09)$ \\
\hline 2-Furaldehyde (furfural) & $\mathrm{C}_{5} \mathrm{H}_{4} \mathrm{O}_{2}$ & $1.61(0.81)$ & $1.82(0.85)$ & $1.35(0.75)$ & $1.34(0.85)$ & $2.78(1.21)$ \\
\hline 2,5-Dimethylfuran ${ }^{\mathrm{a}}$ & $\mathrm{C}_{6} \mathrm{H}_{8} \mathrm{O}$ & $0.27(0.09)$ & $0.58(0.20)$ & 0.615573 & $0.11(0.01)$ & $0.62(0.77)$ \\
\hline Furfuryl alcohol & $\mathrm{C}_{5} \mathrm{H}_{6} \mathrm{O}_{2}$ & $0.77(0.49)$ & $1.23(0.57)$ & $0.85(0.44)$ & $0.25(0.21)$ & $1.98(1.21)$ \\
\hline Methylfurfural $^{\mathrm{b}}$ & $\mathrm{C}_{6} \mathrm{H}_{6} \mathrm{O}_{2}$ & $0.42(0.24)$ & $1.18(0.89)$ & $1.95(1.49)$ & $0.44(0.35)$ & $0.98(0.52)$ \\
\hline Benzofuran & $\mathrm{C}_{8} \mathrm{H}_{6} \mathrm{O}$ & $0.059(0.028)$ & $0.11(0.05)$ & $0.10(0.05)$ & $0.017(0.010)$ & $0.10(0.04)$ \\
\hline Hydroxymethylfurfural & $\mathrm{C}_{6} \mathrm{H}_{6} \mathrm{O}_{3}$ & $0.21(0.16)$ & $0.64(0.43)$ & $0.28(0.19)$ & $0.18(0.14)$ & $0.49(0.35)$ \\
\hline Methylbenzofuran isomers ${ }^{\mathrm{a}}$ & $\mathrm{C}_{9} \mathrm{H}_{8} \mathrm{O}$ & $0.67(0.58)$ & - & - & - & - \\
\hline
\end{tabular}

tion. An identical or similar approach that incorporates the additional aromatics detected by PTR-TOF-MS in this work may be useful to predict the contribution of aromatics from BB to global SOA by various reaction pathways.

Toluene, another major emission, often serves as a model compound to study the formation of SOA from other small ringed volatile organic compounds (Hildebrandt et al., 2009). Black spruce yielded the greatest toluene ER (to benzene) during FLAME-4 (3.24 \pm 0.42$)$ and has been linked to significant $\mathrm{OA}$ enhancement during chamber photo-oxidation aging experiments investigating open $\mathrm{BB}$ emissions during FLAME-3, though toluene was not significant enough to account for all of the observed SOA (Hennigan et al., 2011).

Naphthalene is the simplest species in a class of carcinogenic and neurotoxic compounds known as polycyclic aro- matic hydrocarbons (PAH) and was detected from all fuels. The rapid rate of photo-oxidation of these smaller ringed gas-phase PAHs (including naphthalene and methylnaphthalenes) can have important impacts on the amount and properties of SOA formed and yields significantly more SOA over shorter time spans in comparison to lighter aromatics (Chan et al., 2009). Under low- $\mathrm{NO}_{\mathrm{x}}$ conditions (BB events generate $\mathrm{NO}_{\mathrm{x}}$, though at lower ratios to $\mathrm{NMOC}$ and/or $\mathrm{CO}$ than those present in urban environments) the SOA yield for benzene, toluene, and $m$-xylene was $\sim 30 \%$ ( $\mathrm{Ng}$ et al., 2007), while naphthalene yielded enhancements as great as $73 \%$ (Chan et al., 2009).

In summary, many of the species identified and detected during FLAME-4 are associated with aerosol formation under diverse ambient conditions (Fisseha et al., 2004; Na et 
Table 2b. Continued.

\begin{tabular}{|c|c|c|c|c|c|c|c|}
\hline & $\begin{array}{r}\text { Crop } \\
\text { residue } \\
(\text { feed, } 9)\end{array}$ & $\begin{array}{r}\text { Open three- } \\
\text { stone } \\
\text { cooking }(3)\end{array}$ & $\begin{array}{r}\text { Rocket } \\
\text { cookstoves } \\
(5)\end{array}$ & $\begin{array}{r}\text { Gasifier } \\
\text { cookstove } \\
(1)\end{array}$ & $\begin{array}{r}\text { Trash } \\
(2)\end{array}$ & $\begin{array}{r}\text { Tires } \\
(1)\end{array}$ & $\begin{array}{r}\text { Plastic } \\
\text { bags } \\
(1)\end{array}$ \\
\hline ER/benzene; MCE & $0.940(0.017)$ & $0.968(0.004)$ & $0.972(0.015)$ & 0.984 & $0.973(0.006)$ & 0.961 & 0.994 \\
\hline Toluene & $1.00(0.44)$ & $0.095(0.029)$ & $0.98(1.39)$ & 0.24 & $0.41(0.20)$ & 0.056 & 0.69 \\
\hline Phenylacetylene & $0.14(0.09)$ & $0.10(0.05)$ & - & - & - & 0.020 & - \\
\hline Styrene & $0.14(0.05)$ & $0.054(0.021)$ & $0.076(0.023)$ & 0.042 & $0.86(0.16)$ & 0.064 & 0.094 \\
\hline Xylenes/ethylbenzene & $0.24(0.11)$ & $0.052(0.034)$ & $0.10(0.05)$ & 0.048 & $0.095(0.017)$ & 0.043 & 0.029 \\
\hline Trimethylbenzene & $0.11(0.06)$ & $0.014(0.007)$ & $0.050(0.048)$ & 0.026 & $0.033(0.016)$ & 0.011 & 0.047 \\
\hline Naphthalene & $0.18(0.11)$ & $0.21(0.05)$ & $0.30(0.17)$ & 0.12 & 0.10 & 0.19 & 0.059 \\
\hline Dihydronaphthalene & $0.051(0.021)$ & $0.019(0.006)$ & - & - & - & $9.81 \times 10^{-3}$ & - \\
\hline$p$-Cymene ${ }^{\mathrm{a}}$ & $0.11(0.03)$ & $4.10 \times 10^{-3}$ & - & $\mathrm{nm}$ & 0.018 & $\mathrm{~nm}$ & $\mathrm{~nm}$ \\
\hline Methylnaphthalenes & $0.057(0.037)$ & - & - & - & - & 0.031 & - \\
\hline \multicolumn{8}{|l|}{ ER/phenol } \\
\hline Cresols (methylphenols) ${ }^{\mathrm{a}}$ & $0.61(0.14)$ & - & $0.34(0.28)$ & $\mathrm{nm}$ & $\mathrm{nm}$ & $\mathrm{nm}$ & $\mathrm{nm}$ \\
\hline Catechol (benzenediols) ${ }^{\mathrm{b}}$ & $0.67(0.30)$ & $0.74(0.65)$ & $1.86(1.29)$ & 0.49 & $1.12(0.65)$ & 0.082 & 0.31 \\
\hline Vinylphenol & $0.29(0.06)$ & $0.18(0.06)$ & $0.25(0.18)$ & 0.14 & $0.34(0.02)$ & 0.17 & 0.33 \\
\hline Salicylaldehyde & $0.11(0.04)$ & $0.16(0.06)$ & $0.27(0.15)$ & 0.22 & $0.28(0.09)$ & 0.17 & - \\
\hline Xylenol (2,5-dimethyl phenol) & $0.33(0.07)$ & $0.18(0.09)$ & $0.35(0.11)$ & 0.11 & $0.23(0.00)$ & 0.026 & - \\
\hline Guaiacol (2-methoxyphenol) & $0.47(0.16)$ & $0.52(0.40)$ & $1.30(0.73)$ & 0.31 & $0.54(0.32)$ & 0.019 & 2.02 \\
\hline Creosol (4-methylguaiacol) ${ }^{\mathrm{a}}$ & $0.24(0.07)$ & 0.46 & $0.62(0.23)$ & $\mathrm{nm}$ & 0.043 & $\mathrm{~nm}$ & $\mathrm{~nm}$ \\
\hline 3-Methoxycatechol ${ }^{\mathrm{a}}$ & $0.063(0.035)$ & 0.28 & 0.44 & $\mathrm{~nm}$ & 0.14 & $\mathrm{~nm}$ & $\mathrm{~nm}$ \\
\hline 4-Vinylguaiacol ${ }^{\mathrm{a}}$ & $0.31(0.11)$ & 0.34 & $0.35(0.22)$ & $\mathrm{nm}$ & 0.054 & $\mathrm{~nm}$ & $\mathrm{~nm}$ \\
\hline Syringol $^{\mathrm{a}}$ & $0.12(0.02)$ & 0.94 & $0.92(0.53)$ & $\mathrm{nm}$ & - & $\mathrm{nm}$ & $\mathrm{nm}$ \\
\hline \multicolumn{8}{|l|}{ ER/furan } \\
\hline 2-Methylfuran & $1.36(0.38)$ & $0.95(0.33)$ & $1.66(1.95)$ & 0.55 & $0.64(0.02)$ & 2.10 & 2.10 \\
\hline 2-Furanone & $1.16(0.56)$ & $0.73(0.21)$ & $2.37(3.39)$ & 1.28 & $1.04(0.49)$ & 3.02 & - \\
\hline 2-Furaldehyde (furfural) & $1.69(0.96)$ & $2.47(1.84)$ & $5.69(8.46)$ & 1.26 & $1.03(0.29)$ & 2.09 & 0.39 \\
\hline 2,5-Dimethylfuran ${ }^{\mathrm{a}}$ & $0.98(0.14)$ & - & - & $\mathrm{nm}$ & 0.2715416 & $\mathrm{~nm}$ & $\mathrm{~nm}$ \\
\hline Furfuryl alcohol & $1.21(0.55)$ & $0.86(0.25)$ & 1.35 & 0.00 & $0.78(0.31)$ & 1.06 & 1.03 \\
\hline Methylfurfural $^{\mathrm{b}}$ & $0.90(0.42)$ & $0.59(0.20)$ & $1.06(1.32)$ & 0.37 & $0.38(0.06)$ & 1.33 & 0.093 \\
\hline Benzofuran & $0.11(0.05)$ & $0.39(0.57)$ & $0.041(0.030)$ & 0.069 & $0.058(0.018)$ & 2.79 & 0.056 \\
\hline Hydroxymethylfurfural & $0.27(0.14)$ & $0.20(0.06)$ & $0.44(0.52)$ & 0.30 & $0.39(0.22)$ & 0.28 & - \\
\hline Methylbenzofuran isomers ${ }^{\mathrm{a}}$ & - & - & - & $\mathrm{nm}$ & - & $\mathrm{nm}$ & $\mathrm{nm}$ \\
\hline
\end{tabular}

Note: "nm" indicates not measured; blank indicates species remained below the detection limits; values in parentheses indicate one standard deviation.

a Species were only selected for a few key fires and are not considered the average of each fuel type.

b Significant contributions from both methylfurfural and catechol were reported in pyrolysis reference papers, thus there is no indication which species is the major contributor at this mass.

al., 2006; $\mathrm{Ng}$ et al., 2007; Chan et al., 2009). We present here initial emissions for a variety of aromatics from major global fuels. A more focused study to probe the extent and significance of SOA formation in BB plumes by these aromatic precursors was performed by chamber oxidation during the FLAME-4 campaign and will be presented in Tkacik et al. (2014).

\subsection{Phenolic compounds}

Phenol is detected at $m / z$ 95. Earlier studies burning a variety of biomass fuels found that OP-FTIR measurements of phenol accounted for the observed PTR-MS signal at this mass even at unit mass resolution, though small contribu- tions from other species such as vinyl furan were possible but not detected (Christian et al., 2004). 2D-GC grab samples in FLAME-4 found that other species with the same formula (only vinyl furan) were present at levels less than $2 \%$ of phenol (Hatch et al., 2014). Thus, we assumed that within experimental uncertainty, $\mathrm{m} / \mathrm{z} 95$ was a phenol measurement in this study and found that phenol was one of the most abundant oxygenated aromatic compounds detected. Several substituted phenols were speciated for every fire and included catechol $(m / z 111)$, vinylphenol $(m / z 121)$, salicylaldehyde $(\mathrm{m} / \mathrm{z} 123)$, xylenol $(\mathrm{m} / \mathrm{z} 123)$, and guaiacol $(\mathrm{m} / \mathrm{z}$ 125) (Fig. 5a). Several additional species were quantified for selected fires and included cresol $(\mathrm{m} / \mathrm{z} 109)$, creosol $(\mathrm{m} / \mathrm{z}$ 139), 3-methoxycatechol $(\mathrm{m} / \mathrm{z} 141)$, 4-vinylguaiacol $(\mathrm{m} / \mathrm{z}$ 


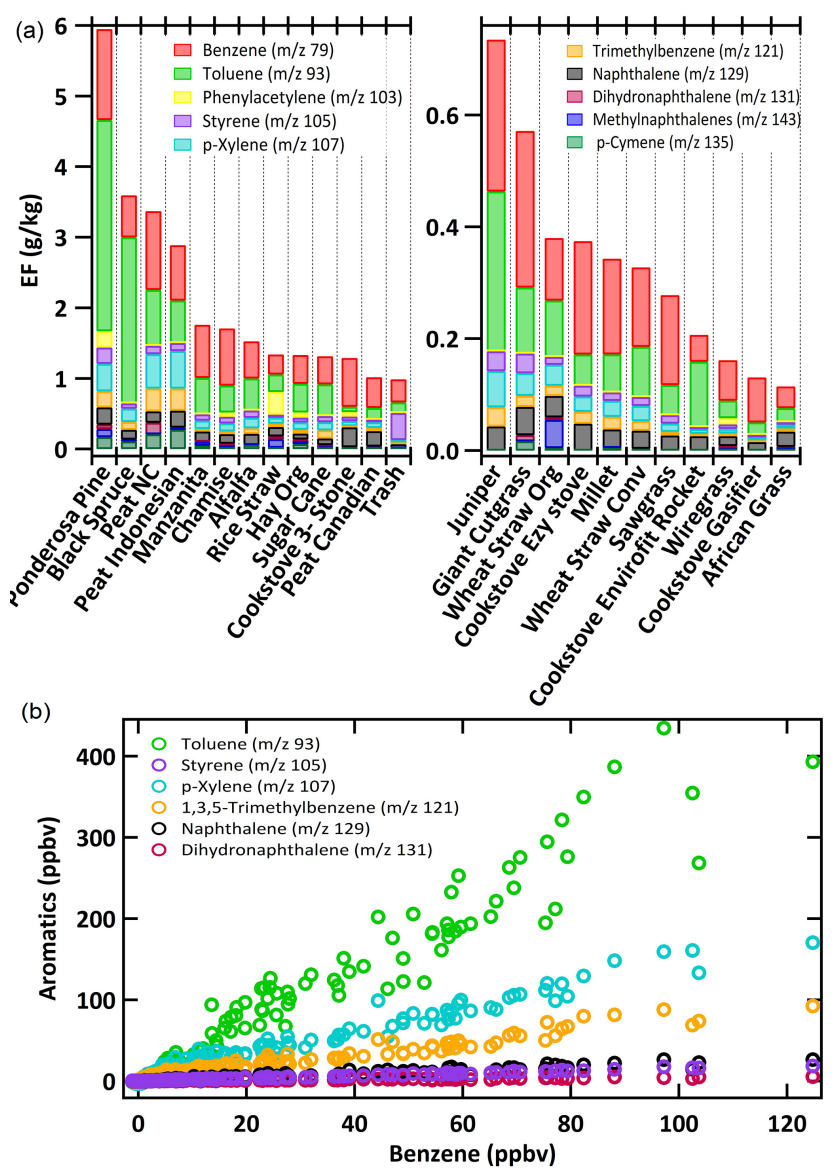

Figure 4. (a) The EFs of the aromatics analyzed in all fires averaged and shown by fuel type. Individual contributions from benzene and other aromatics are indicated by color. The EFs for $p$-cymene are only calculated for select fires and should not be considered a true average. (b) The correlation plots of selected aromatics with benzene during a black spruce fire (Fire 74). Similar behavior was observed for all other fuel types.

151), and syringol $(m / z$ 155). The EFs for these additional phenolic compounds were calculated for select burns and are included in Fig. 5a with the regularly analyzed compounds. Significant emissions of these compounds are reported in Table 2 relative to phenol, and the selected compounds shown in Fig. 5b demonstrate the tight correlation between these derivatives and phenol.

Phenol, methoxyphenols (guaiacols), dimethoxyphenols (syringol), and their derivatives are formed during the pyrolysis of lignin (Simoneit et al., 1993) and can readily react with $\mathrm{OH}$ radicals leading to SOA formation (Coeur-Tourneur et al, 2010; Lauraguais et al., 2014). Hawthorne et al. (1989, 1992) found that phenols and guaiacols accounted for 21 and $45 \%$ of aerosol mass from wood smoke, while Yee et al. (2013) noted large SOA yields for phenol (24-44\%), guaiacol (44-
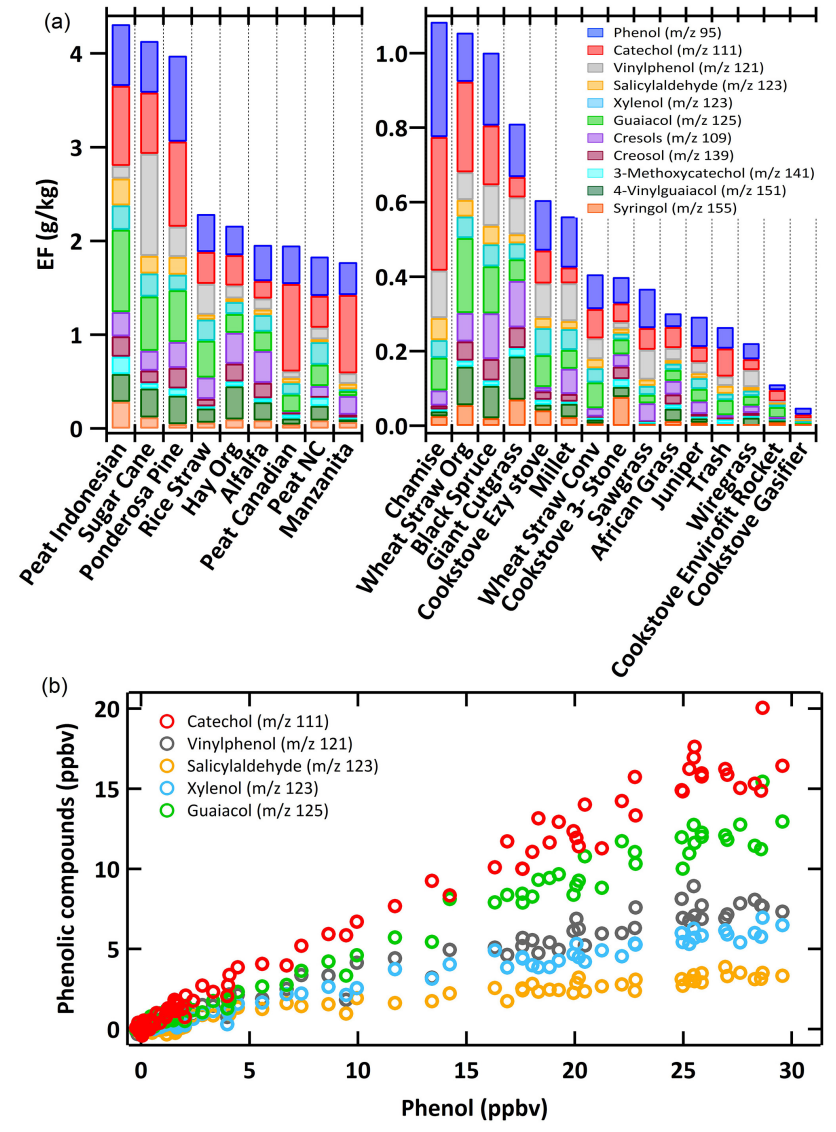

Figure 5. (a) The distribution in average fuel EF for several phenolic compounds, where compound-specific contributions are indicated by color. The EFs for compounds additionally analyzed a single time for select fires are included but are not a true average. (b) The linear correlation of select phenolic compounds with phenol during an organic hay burn (Fire 119).

$50 \%$ ), and syringol (25-37\%) by photo-oxidation chamber experiments under low- $\mathrm{NO}_{\mathrm{x}}$ conditions $(<10 \mathrm{ppb})$.

Softwoods are considered lignin-rich and are associated predominately with guaiacyl units (Shafizadeh, 1982). Thus not surprisingly, guaiacol emissions were significant for ponderosa pine. Peat, an accumulation of decomposing vegetation (moss, herbaceous, woody materials), has varying degrees of lignin content depending on the extent of decomposition, sampling depth, water table levels, etc. (Williams et al., 2003). The peat burns all emitted significant amounts of phenolic compounds, with noticeable compound-specific variability between regions (Indonesia, Canada, and North Carolina). It is also noteworthy that sugar cane, which also produced highly oxygenated emissions based on FTIR and PTR-TOF-MS results, had the greatest total emissions of phenolic compounds.

The photochemical formation of nitrophenols and nitroguaiacols by atmospheric oxidation of phenols and substituted phenols via $\mathrm{OH}$ radicals in the presence of $\mathrm{NO}_{\mathrm{x}}$ is 
a potential reaction pathway for these compounds (Atkinson et al., 1992; Olariu et al., 2002; Harrison et al., 2005; Lauraguais et al., 2014). Nitration of phenol in either the gas or aerosol phase is anticipated to account for a large portion of nitrophenols in the environment. Higher nitrophenol levels are correlated with increased plant damage (Hinkel et al., 1989; Natangelo et al., 1999) and consequently are linked to forest decline in central Europe and North America (Rippen et al., 1987). Nitrophenols are also important components of brown carbon and can contribute to SOA formation in BB plumes (Kitanovski et al., 2012; Desyaterik et al., 2013; Mohr et al., 2013; Zhang et al., 2013). Nitrated phenols including nitroguaiacols and methyl-nitrocatechols are suggested as suitable BB molecular tracers for secondary $\mathrm{BB}$ aerosol considering their reactivity with atmospheric oxidants is limited (Iinuma et al., 2010; Kitanovski et al., 2012; Lauraguais et al., 2014). The oxidation products from the phenolic compounds detected in fresh smoke here have not been directly examined and would require a more focused study beyond the scope of this paper.

As with the aromatic compounds, the ERs provided in Table 2 can be used to estimate initial BB emissions of phenolic species, both rarely measured or previously unmeasured, from a variety of fuels in order to improve atmospheric modeling of SOA and nitrophenol formation.

\subsection{Furans}

Other significant oxygenated compounds include furan and substituted furans which arise from the pyrolysis of cellulose and hemicellulose. The substituted furans regularly quantified included 2-methylfuran $(\mathrm{m} / \mathrm{z} 83), 2$-furanone $(\mathrm{m} / \mathrm{z}$ $85)$, furfural $(m / z$ 97), furfuryl alcohol $(m / z 99)$, methylfurfural $(\mathrm{m} / \mathrm{z} 111)$, benzofuran $(\mathrm{m} / \mathrm{z} 119)$, and hydroxymethylfurfural $(m / z$ 127), while 2,5-dimethylfuran $(m / z$ 97) and methylbenzofurans $(m / z, 133)$ were occasionally quantified. The ERs to furan for these compounds are summarized in Table 2, and Fig. 6a shows the average EF for the regularly quantified masses and the individual fire EFs for the occasionally quantified compounds.

Furan and substituted furans are oxidized in the atmosphere primarily by $\mathrm{OH}$ (Bierbach et al., 1995), but also by $\mathrm{NO}_{3}$ (Berndt et al., 1997) or $\mathrm{Cl}$ atoms (Cabañas et al., 2005; Villanueva et al., 2007). Photo-oxidation of furan, 2methylfuran, and 3-methylfuran produces butenedial, 4-oxo2-pentenal, and 2-methylbutenedial (Bierbach et al 1994, 1995). These products are highly reactive and can lead to free radical (Wagner et al., 2003), $\mathrm{SOA}$, or $\mathrm{O}_{3}$ formation. In fact, aerosol formation from photo-oxidation chamber experiments has been observed for furans and their reactive intermediates listed above (Gomez Alvarez et al., 2009; Strollo and Ziemann, 2013). Even less is known concerning SOA yields from furans with oxygenated functional groups, which comprise the majority of the furan emissions in this study. Alvarado and Prinn (2009) added reaction rates for furans
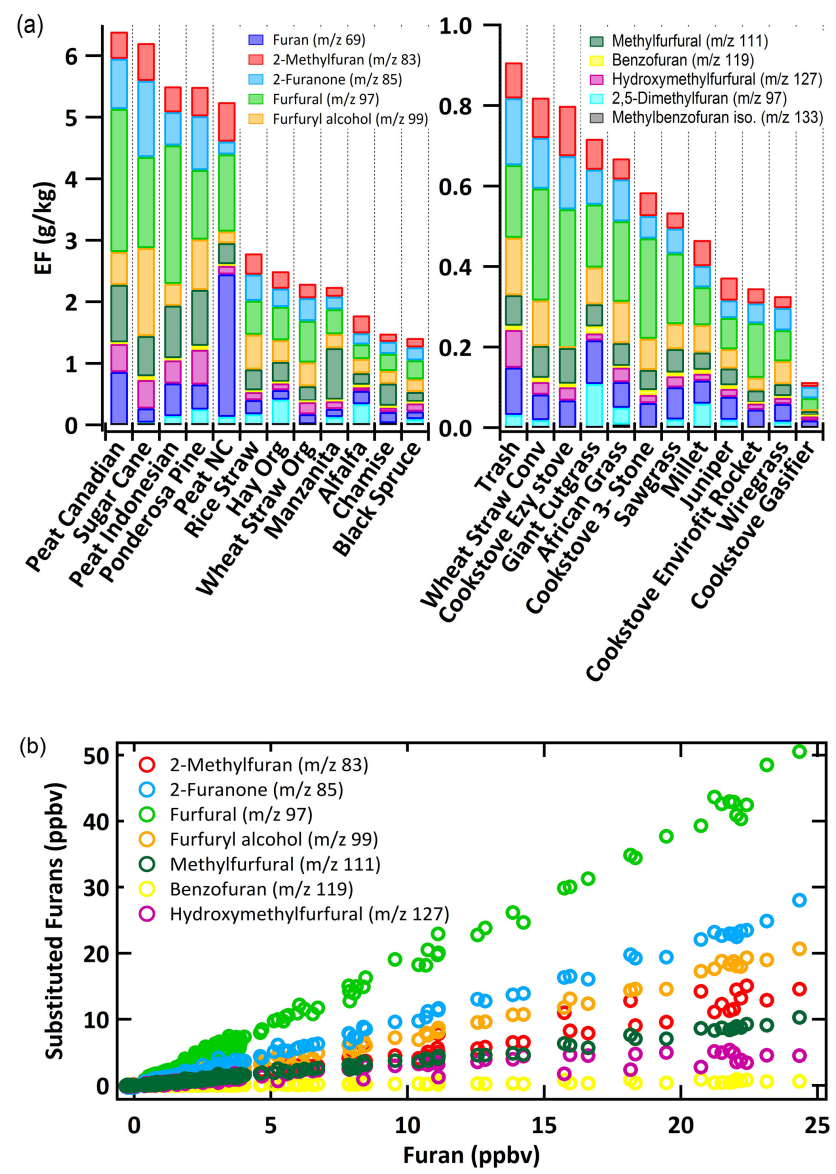

Figure 6. (a) The distribution in average fuel EF for furan and substituted furans, where individual contributions are indicated by color. The EFs for substituted furans additionally analyzed a single time are not true averages (b) The linear correlation of furan with select substituted furans for an African grass fire (Fire 49).

based on 2-methylfuran and butenedial values (Bierbach et al., 1994, 1995) to model $\mathrm{O}_{3}$ formation in an aging savanna smoke plume. Although a slight increase in $\mathrm{O}_{3}$ was observed after $60 \mathrm{~min}$, it was not large enough to account for the observed $\mathrm{O}_{3}$ concentrations in the plume. The furan and substituted furan ERs compiled here may help explain a portion of the SOA and $\mathrm{O}_{3}$ produced from fires that cannot be accounted for based upon previously implemented precursors (Grieshop et al., 2009).

Furfural was generally the dominant emission in this grouping, consistent with concurrent 2D-GC measurements (Hatch et al., 2014), while emissions from 2-furanone and furan also contributed significantly. Friedli et al. (2001) observed that ERs of alkyl furans linearly correlated with furan and concluded that these alkylated compounds likely break down to furan. Our expanded substituted furan list includes a variety of functionality ranging from oxygenated substituents to those fused with benzene rings for diverse fuel types. Similar to the behavior observed for alkylated fu- 
rans, the emissions of our substituted furans linearly correlate with furan as shown in Fig. 6b. As noted for phenolic compounds, sugar cane produced the largest emissions of furans excluding Canadian peat, supporting sugar cane as an important emitter of oxygenated compounds. The emissions from furan, phenol, and their derivatives reflect variability in cellulose and lignin composition of different fuel types. Cellulose and hemicellulose compose $\sim 75 \%$ of wood while lignin only accounts for $\sim 25 \%$ on average (Sjöström, 1993). Accordingly, the $\Sigma$ furans $/ \Sigma$ phenols for initially analyzed compounds indicate that furans are dominant in nearly every fuel type.

\subsection{Nitrogen-containing compounds}

Many N-containing peaks were not originally selected for post-acquisition analysis in every fire. However, the additional analysis of selected fires included a suite of $\mathrm{N}$ containing organic compounds to investigate their potential contribution to the $\mathrm{N}$ budget and new particle formation (NPF). Even at our mass resolution of $\sim 5000$, the mass peak from $\mathrm{N}$ compounds can sometimes be overlapped by broadened ${ }^{13} \mathrm{C}$ "isotope" peaks of major carbon-containing emissions. This interference was not significant for the following species that we were able to quantify in the standard or added analysis: $\mathrm{C}_{2} \mathrm{H}_{3} \mathrm{~N}$ (acetonitrile, calibrated), $\mathrm{C}_{2} \mathrm{H}_{7} \mathrm{~N}$ (dimethylamine; ethylamine), $\mathrm{C}_{2} \mathrm{H}_{5} \mathrm{NO}$ (acetamide), $\mathrm{C}_{3} \mathrm{H}_{9} \mathrm{~N}$ (trimethylamine), $\mathrm{C}_{4} \mathrm{H}_{9} \mathrm{NO}$ (assorted amides), $\mathrm{C}_{4} \mathrm{H}_{11} \mathrm{NO}$ (assorted amines), and $\mathrm{C}_{7} \mathrm{H}_{5} \mathrm{~N}$ (benzonitrile). As illustrated by the multiple possibilities for some formulas, several quantified N-containing species were observed but explicit single identities or relative contributions could not be confirmed. The logical candidates we propose are based upon atmospheric observations and include classes of amines and amides shown in Table S4 (Lobert et al., 1991; Schade and Crutzen, 1995; Ma and Hays et al., 2008; Barnes et al., 2010; Ge et al., 2011). Additional N-containing compounds were clearly observed in the mass spectra such as acrylonitrile, propanenitrile, pyrrole, and pyridine, but they were often overlapped with isotopic peaks of major carbon compounds; thus a time-intensive analysis would be necessary to provide quantitative data. For the species in this category, quantification was possible for select fires by 2D-GC-MS and they are reported by Hatch et al. (2014) for the FLAME-4 campaign.

We present in Supplement Table S5 the abundance of each $\mathrm{N}$-containing gas quantified by PTR-TOF-MS and FTIR relative to $\mathrm{NH}_{3}$ for selected fires. The additional $\mathrm{N}$-containing organic gases detected by PTR-TOF-MS for these 29 fires summed to roughly $22 \pm 23 \%$ of $\mathrm{NH}_{3}$ on average and accounted for a range of $0.1-8.7 \%$ of the fuel N. These compounds contributed most significantly to fuel $\mathrm{N}$ for peat and this varied by sampling location. This is not surprising since environmental conditions and field sampling depths varied considerably. Stockwell et al. (2014) reported large differences for N-containing compounds quantified by FTIR be- tween FLAME-4 and earlier laboratory studies of emissions from peat burns. In any case, the additional NMOCs (including N-containing compounds) speciated by PTR-TOF-MS substantially increases the amount of information currently available on peat emissions.

The relevance of the $\mathrm{N}$-containing organics to climate and the $\mathrm{N}$ cycle is briefly summarized next. Aerosol particles acting as cloud condensation nuclei (CCN) critically impact climate by production and modification of clouds and precipitation (Novakov and Penner, 1993). NPF, the formation of new stable nuclei, is suspected to be a major contributor to the amount of CCN in the atmosphere (Kerminen et al., 2005; Laaksonen et al., 2005; Sotiropoulou et al., 2006). Numerous studies have suggested that organic compounds containing $\mathrm{N}$ can play an important role in the formation and growth of new particles (Smith et al., 2008; Kirkby et al., 2011; Yu and Luo, 2014). The primary pathways to new particle formation include (1) the reaction of organic compounds with each other or atmospheric oxidants to form higher molecular weight, lower volatility compounds that subsequently partition into the aerosol phase or (2) rapid acid/base reactions forming organic salts. The observation of significant emissions of N-containing organic gases in FLAME4 could improve understanding of the compounds, properties, and source strengths contributing to new particle formation and enhance model predictions on local to global scales. The identities and amounts of these additional N-containing emissions produced by peat and other BB fuels are also important in rigorous analysis of the atmospheric $\mathrm{N}$ budget.

\subsection{Sulfur, phosphorous, and chlorine-containing compounds}

S emissions are important for their contribution to acid deposition and climate effects due to aerosol formation. Several Scontaining gases have been detected in BB emissions including $\mathrm{SO}_{2}$, carbonyl sulfide (OCS), dimethyl sulfide (DMS), and dimethyl disulfide (DMDS); DMS is one of the most significant organosulfur compounds emitted by BB and is quantified by PTR-TOF-MS in our primary data set (Friedli et al., 2001; Meinardi et al., 2003; Akagi et al., 2011; Simpson et al., 2011). The signal at $m / z 49$ had a significant mass defect and is attributed to methanethiol (methyl mercaptan, $\mathrm{CH}_{3} \mathrm{SH}$ ), which to our knowledge has not been previously reported in real-world BB smoke, though it has been observed in cigarette smoke (Dong et al., 2010) and in emissions from pulp and paper plants (Toda et al., 2010). Like DMS, the photochemical oxidation of $\mathrm{CH}_{3} \mathrm{SH}$ leads to $\mathrm{SO}_{2}$ formation (Shon and Kim, 2006), which can be further oxidized to sulfate or sulfuric acid and contribute to the aerosol phase. The emissions of $\mathrm{CH}_{3} \mathrm{SH}$ are dependent on the fuel $\mathrm{S}$ content and are negatively correlated with $\mathrm{MCE}$. The greatest $\mathrm{EF}\left(\mathrm{CH}_{3} \mathrm{SH}\right)$ in our additional analyses arose from organic alfalfa, which had the highest $\mathrm{S}$ content of the selected fuels 
and also produced significant emissions of $\mathrm{SO}_{2}$ detected by FTIR.

Other organic gases containing chlorine and phosphorous were expected to be readily detectable because of their large, unique mass defects and possible enhancement by pesticides and fertilizers in crop residue fuels. However, they were not detected in significant amounts by our full mass scans. Fuel $P$ and $\mathrm{Cl}$ may have been emitted primarily as aerosol, ash, low proton affinity gases, or as a suite of gases that were evidently below our detection limit.

\subsection{Miscellaneous (order of increasing $m / z$ )}

\section{$m / z$ 41:}

The assignment of propyne is reinforced by previous observations in BB fires, and it is of some interest as a BB marker even though it has a relatively short lifetime of $\sim 2$ days (Simpson et al., 2011; Akagi et al., 2013; Yokelson et al., 2013). Considering that propyne was not detected in every fuel type, a level of uncertainty is added to any use of this compound as a BB tracer, and in general the use of multiple tracers is preferred when possible.

$m / z$ 43:

The high-resolution capabilities of the PTR-TOF-MS allowed propylene to be distinguished from ketene fragments at $m / z$ 43. The propylene concentrations are superseded in our present data set by FTIR measurements; however, the two techniques agree well.

\section{$m / z$ 45:}

PTR technology has already been reported as a reliable way to measure acetaldehyde in BB smoke (Holzinger et al., 1999; Christian et al., 2004). Photolysis of acetaldehyde can play an important role in radical formation and is the main precursor of peroxy acetyl nitrate (PAN) (Trentmann et al., 2003). A wide range in EF (acetaldehyde) $\left(0.13-4.3 \mathrm{~g} \mathrm{~kg}^{-1}\right)$ is observed during FLAME-4 and reflects variability in fuel type. The detailed emissions from a range of fuels in this data set can aid in modeling and interpretation of PAN formation in aging BB plumes of various regions (Alvarado et al., 2010, 2013). Crop-residue fuels regularly had the greatest emissions of acetaldehyde, which is important considering many crop-residue fires evade detection and are considered both regionally and globally underestimated. Sugar cane burning had the largest acetaldehyde EF $\left(4.3 \pm 1.4 \mathrm{~g} \mathrm{~kg}^{-1}\right)$ and had significant emissions of oxygenated and N-containing compounds; consequently it is likely to form a significant amount of PAN. $m / z$ 57:

The signal at $m / z 57$ using unit-mass resolution GC-PTRMS was observed to be primarily acrolein with minor contributions from alkenes (Karl et al., 2007). In the PTR-TOF$\mathrm{MS}$, the two peaks at $\mathrm{m} / z 57\left(\mathrm{C}_{3} \mathrm{H}_{5} \mathrm{O}^{+}\right.$and $\left.\mathrm{C}_{4} \mathrm{H}_{9}^{+}\right)$are clearly distinguished and acrolein is often the dominant peak during the fire with the highest emissions from ponderosa pine and sugar cane.

\section{$m / z$ 69:}

The high resolution of the PTR-TOF-MS allowed three peaks to be distinguished at $m / z 69$, identities attributed to carbon suboxide $\left(\mathrm{C}_{3} \mathrm{O}_{2}\right)$, furan $\left(\mathrm{C}_{4} \mathrm{H}_{4} \mathrm{O}\right)$, and mostly isoprene $\left(\mathrm{C}_{5} \mathrm{H}_{8}\right)$ (Fig. 7). Distinguishing between isoprene and furan is an important capability of the PTR-TOF-MS. The atmospheric abundance and relevance of carbon suboxide is fairly uncertain and with an atmospheric lifetime of $\sim 10$ days (Kessel et al., 2013), the reactivity and transport of $\mathrm{C}_{3} \mathrm{O}_{2}$ emitted by fires could have critical regional impacts. The emissions of $\mathrm{C}_{3} \mathrm{O}_{2}$ by $\mathrm{BB}$ will be interpreted in detail at a later date (S. Kessel, personal communication, 2014).

$m / z$ 75:

Hydroxyacetone emissions have been reported from both field and laboratory fires (Christian et al., 2003; Akagi et al., 2011; Yokelson et al., 2013; St. Clair et al., 2014). Christian et al. (2003) first reported BB emissions of hydroxyacetone and noted very large quantities from burning rice straw. The $\mathrm{EF}\left(\mathrm{C}_{3} \mathrm{H}_{6} \mathrm{O}_{2}\right)$ for rice straw was noticeably high $\left(1.1 \mathrm{~g} \mathrm{~kg}^{-1}\right)$ in the FLAME-4 data set and only sugar cane had greater emissions.

\section{$m / z$ 85, 87:}

The largest peak at $m / z 85$ was assigned as pentenone as it was monitored/confirmed by PIT-MS/GC-MS in an earlier BB study (Yokelson et al., 2013). Pentenone was a substantial emission from several fuels with ponderosa pine having the greatest EF. By similar evidence the minor peak at $m / z$ 87 was assigned to pentanone but was only detected in a few of the fires in the second set of analyses with the most significant emissions arising from Indonesian peat.

\section{$m / z$ 107:}

Benzaldehyde has the same unit mass as xylenes, but is clearly separated by the TOF-MS. Greenberg et al. (2006) observed benzaldehyde during low-temperature pyrolysis experiments with the greatest emissions from ponderosa needles (ponderosa pine produced the greatest EF in our data set, with a range of $\left.0.1-0.28 \mathrm{~g} \mathrm{~kg}^{-1}\right)$. Benzaldehyde emissions were additionally quantified by GC-MS during a laboratory $\mathrm{BB}$ campaign and produced comparable EF to that of xylenes 


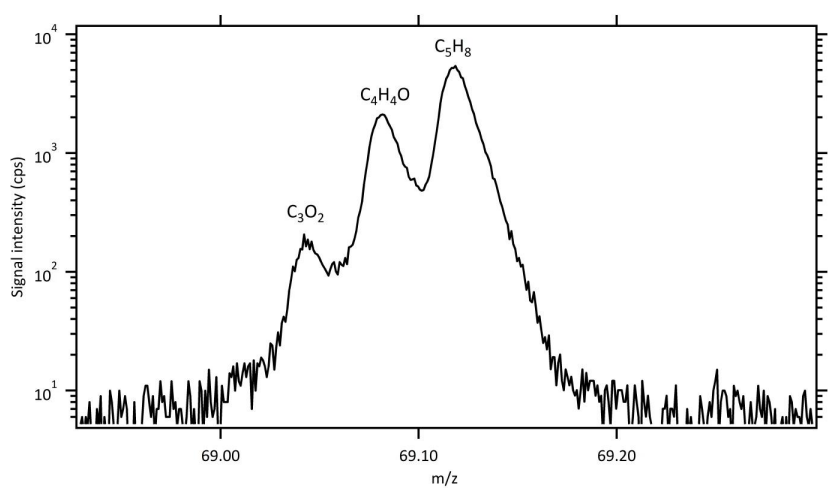

Figure 7. Expanded view of the PTR-TOF-MS spectrum at $m / z 69$ demonstrating the advantage over unit mass resolution instruments of distinguishing multiple peaks, in this instance separating carbon suboxide $\left(\mathrm{C}_{3} \mathrm{O}_{2}\right)$, furan $\left(\mathrm{C}_{4} \mathrm{H}_{4} \mathrm{O}\right)$, and mostly isoprene $\left(\mathrm{C}_{5} \mathrm{H}_{8}\right)$ in ponderosa pine smoke (fire 70).

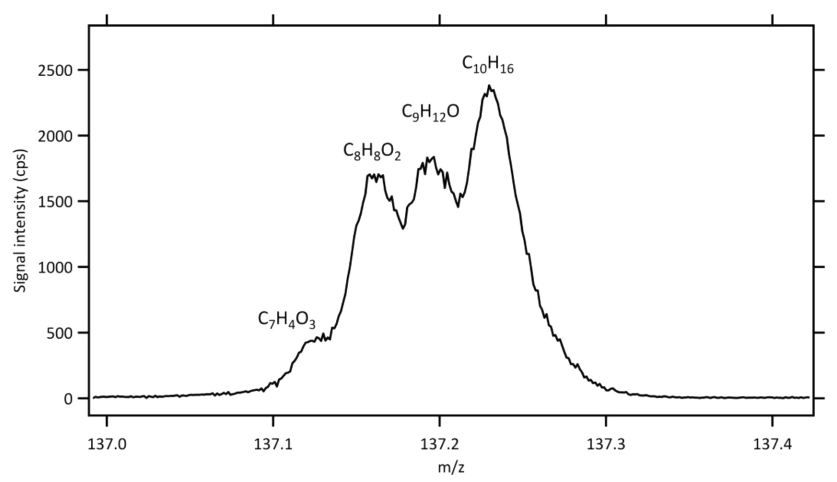

Figure 8. Expanded view of the PTR-TOF-MS spectrum of NC peat (fire 61) at $m / z 137$ showing multiple peaks.

(Yokelson et al., 2013). During FLAME-4 the EF (benzaldehyde) was comparable to EF (xylenes calibrated as $p$-xylene) as seen earlier, except for peat burns where xylenes were significantly higher.

$m / z$ 137:

At unit mass resolution, the peak at $m / z 137$ is commonly recognized as monoterpenes, which can further be speciated by GC-MS. However, as shown in Fig. 8 there can be up to three additional peaks at this mass that presently remain unidentified oxygenated compounds. As anticipated, the hydrocarbon monoterpene peak is significant for coniferous fuels such as ponderosa pine but much smaller for grasses. In this work we calibrated for $\alpha$-pinene, which has been reported as a major monoterpene emission from fresh smoke (Simpson et al., 2011; Akagi et al., 2013).

\subsection{Cookstoves}

Trace gas emissions were measured for four cookstoves including a traditional three-stone cooking fire, the most widely used stove design worldwide; two "rocket" type designs (Envirofit G3300 and Ezy stove); and a "gasifier" stove (Philips HD4012). Several studies focus on fuel efficiency of cookstove technology (Jetter et al., 2012), while the detailed emissions of many rarely measured and previously unmeasured gases are reported here and in Stockwell et al. (2014) for FLAME-4 burns. For cooking fires, 3-6\% of the NMOC mass remained unidentified, with the Envirofit rocket stove design generating the smallest percentage in the study. To improve the representativeness of our laboratory open cooking emissions, the EFs of smoldering compounds reported for three-stone cooking fires were adjusted by multiplying the mass ratio of each species " $\mathrm{X}$ " to $\mathrm{CH}_{4}$ by the literature-average field $\mathrm{EF}\left(\mathrm{CH}_{4}\right)$ for open cooking in Akagi et al. (2011). Flaming compounds were adjusted by a similar procedure based on their ratios to $\mathrm{CO}_{2}$. The preferred values are reported in Table S3. With these adjustments, the emissions of aromatic hydrocarbons (Fig. 9a), phenolic compounds (Fig. 9b), and furans (Fig. 9c) distinctively increased with the primitiveness of design; thus, three-stone cooking fires produced the greatest emissions. The advancement in emissions characterization for these sources will be used to upgrade models of exposure to household air pollution and the ERs/EFs should be factored in to chemical-transport models to assess atmospheric impacts.

$\mathrm{BB}$ is an important source of reactive $\mathrm{N}$ in the atmosphere, producing significant emissions of $\mathrm{NO}_{\mathrm{x}}$ and $\mathrm{NH}_{3}$ while nonreactive $\mathrm{HCN}$ and $\mathrm{CH}_{3} \mathrm{CN}$ are commonly used as $\mathrm{BB}$ marker compounds (Yokelson et al., 1996, 2007; Goode et al., 1999; de Gouw et al., 2003). The FTIR used in FLAME-4 provided the first detection of $\mathrm{HCN}$ emissions from cooking fires and the HCN/CO ER was about a factor of 5 lower than most other BB fuels burned (Stockwell et al., 2014). Similarly, acetonitrile emissions were measured for the first time for cooking fires by PTR-TOF-MS in this study, and the $\mathrm{CH}_{3} \mathrm{CN} / \mathrm{CO}$ ERs from cooking fires are much lower (on average a factor of $\sim 15$ ) than those from other fuels. This should be considered when using $\mathrm{CH}_{3} \mathrm{CN} / \mathrm{CO}$ ERs to drive source apportionment in areas with substantial emissions from biofuel cooking sources.

\section{Conclusions}

We investigated the primary BB NMOC emissions from laboratory simulated burns of globally significant fuels using a PTR-TOF-MS instrument. In this first PTR-TOF-MS deployment dedicated to fires, we encountered some specific challenges. The fast change in concentration necessitated a fast acquisition rate, which decreased the signal to noise for the emissions above background. The large dynamic con- 

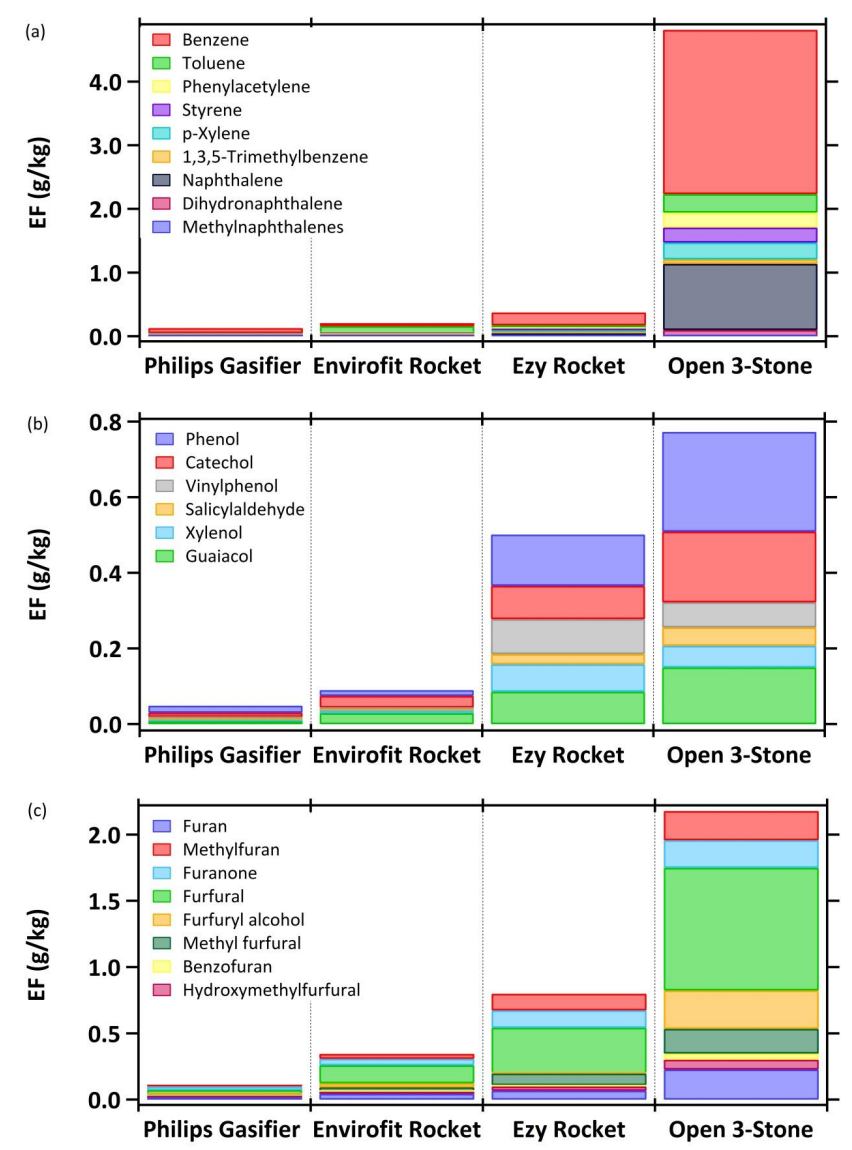

Figure 9. Emission factors $\left(\mathrm{g} \mathrm{kg}^{-1}\right)$ of aromatic hydrocarbons (a), phenolic compounds (b), and furans (c) for traditional and advanced cookstoves. The EFs for traditional stoves were adjusted from original lab data (Sect. 4.7).

centration range necessitated dilution to minimize reagent ion depletion at peak emissions and the dilution further reduced the signal to noise ratio. Positive identification of some species by co-deployed grab sampling techniques will be explored further in a separate paper, but is challenged by the difficulty of transmitting some important fire emissions through GC columns (Hatch et al., 2014). We attempted to enhance compound identification by switching reagent ions $\left(\mathrm{O}_{2}^{+}\right.$and $\left.\mathrm{NO}^{+}\right)$; however, this approach with two broadly sensitive ions in a complex mixture resulted in complex spectra for which comparative analysis is beyond the scope of the present effort. Future experiments might consider instead using a less broadly sensitive reagent ion such as $\mathrm{NH}_{3}^{+}$as the alternate reagent ion. We were limited to our pre-chosen calibration mixture based primarily on gases previously observed in smoke. For future experiments we suggest adding more standards to generate more accurate calibration factors, specifically including major species such as furan and phenol and more compounds with $\mathrm{S}$ and $\mathrm{N}$ heteroatoms. In addition, measuring the fragmentation, if any, of more of the species identified in this work would be of great value. Despite these practical limitations, the experiment produced a great deal of useful new information.

The PTR-TOF-MS obtains full mass scans of NMOCs with high enough resolution to distinguish multiple peaks at the same nominal mass and high enough accuracy to assign chemical formulas from the "exact" masses. This aided in compound identification and more than 100 species were categorized as a confirmed identity, a tentative (most likely) assignment, or unidentified but with a chemical formula. Chemical identification was aided by observations of compounds reported in smoke emissions, pyrolysis experiments, and those species at relevant concentrations in the atmosphere. This allowed the identification of more masses up to $m / z 165$ than in earlier work at unit mass resolution, although an estimated range of $12-37 \%$ of the total mass still remains unidentified and tentatively identified. The analysis provides a new set of emission factors for $\sim 68$ compounds in all fires plus $\sim 50$ more in select fires, in addition to species previously quantified by FTIR (Stockwell et al., 2014) and other techniques during FLAME-4 (Hatch et al., 2014). While significant variability was observed between fuels, oxygenated compounds collectively accounted for the majority of emissions in all fuels, with sugar cane producing the highest EF of oxygenated species on average, possibly due to its high sugar content.

We also report emission ratios to benzene, phenol, or furan for the aromatic hydrocarbons, phenolic compounds, and substituted furans, respectively. Reporting emissions of previously unmeasured or rarely measured compounds relative to these more regularly measured compounds facilitates adding several new compounds to fire emissions models. To our knowledge this is the first on-line, real-time characterization of several compounds within these "families" for BB. Observed emissions varied considerably between fuel types. Several example compounds within each class (toluene, guaiacol, methylfuran, etc.) have been shown, by chamber experiments, to be highly reactive with atmospheric oxidants and contribute significantly to SOA formation. The ERs and EFs characterized by PTR-TOF-MS of fresh BB smoke are presented in Tables S1-S3 and (especially the recommended values in Table S3) should aid model predictions of $\mathrm{O}_{3}$ and SOA formation in BB smoke and the subsequent effects on air quality and climate on local-global scales.

A large number of organic N-containing species were detected with several identities speculated as amines or amides. These N-containing organic gases may play an important role in new particle formation by physical, chemical, and photochemical processes, though a more focused study is necessary to measure NPF yields from these compounds and processes. The additional $\mathrm{N}$-containing gases detected here account for a range of $1-87 \%$ of $\mathrm{NH}_{3}$ dependent on fuel type with the most significant contribution of additional $\mathrm{N}$ species to fuel $\mathrm{N}$ arising from peat burns. The ERs of acetonitrile to $\mathrm{CO}$ for cooking fires were significantly lower than other fuels and should be factored into source apportionment models 
in regions where biofuel use is prevalent if $\mathrm{CH}_{3} \mathrm{CN}$ is used as a tracer.

The S-containing compounds detected by PTR-TOFMS included dimethyl sulfide and methanethiol, where methanethiol was detected for the first time in BB smoke to our knowledge. These compounds may play a role in acid deposition and aerosol formation, though to what extent has yet to be extensively studied. Phosphorous- and chlorinecontaining organic gases were not readily observed in our data set, which may indicate that these species were below our detection limit.

Using full mass scans from a high-resolution PTR-TOFMS to characterize fresh smoke has aided in identifying several compounds and provided the chemical formula of other organic trace gases. The additional NMOCs identified in this work are important for understanding fresh $\mathrm{BB}$ emissions and will improve our understanding of BB atmospheric impacts. The subsequent oxidation products of these gases are the focus of a companion paper probing BB aging. Taken together, this work should improve BB representation in atmospheric models, particularly the formation of ozone and secondary organic aerosol at multiple scales.

\section{The Supplement related to this article is available online at doi:10.5194/acp-15-845-2015-supplement.}

Acknowledgements. FLAME-4, rental of PTR-TOF-MS, and C. S. and R. Y. were supported primarily by NSF grant ATM0936321. FSL operational costs were supported by NASA Earth Science Division Award NNX12AH17G; thanks to S. Kreidenweis, P. DeMott, and G. McMeeking, whose collaboration in organizing and executing FLAME-4 is gratefully acknowledged. The collaboration of A. Robinson in organizing FLAME-4 and the cooking fires is also gratefully acknowledged. We thank C. Geron for providing a sample of NC peat. The research was supported by NASA Earth Science Division Award NNX13AP46G.

Edited by: D. Spracklen

\section{References}

Akagi, S. K., Yokelson, R. J., Wiedinmyer, C., Alvarado, M. J., Reid, J. S., Karl, T., Crounse, J. D., and Wennberg, P. O.: Emission factors for open and domestic biomass burning for use in atmospheric models, Atmos. Chem. Phys., 11, 4039-4072, doi:10.5194/acp-11-4039-2011, 2011.

Akagi, S. K., Craven, J. S., Taylor, J. W., McMeeking, G. R., Yokelson, R. J., Burling, I. R., Urbanski, S. P., Wold, C. E., Seinfeld, J. H., Coe, H., Alvarado, M. J., and Weise, D. R.: Evolution of trace gases and particles emitted by a chaparral fire in California, Atmos. Chem. Phys., 12, 1397-1421, doi:10.5194/acp-121397-2012, 2012.
Akagi, S. K., Yokelson, R. J., Burling, I. R., Meinardi, S., Simpson, I., Blake, D. R., McMeeking, G. R., Sullivan, A., Lee, T., Kreidenweis, S., Urbanski, S., Reardon, J., Griffith, D. W. T., Johnson, T. J., and Weise, D. R.: Measurements of reactive trace gases and variable $\mathrm{O}_{3}$ formation rates in some South Carolina biomass burning plumes, Atmos. Chem. Phys., 13, 1141-1165, doi:10.5194/acp-13-1141-2013, 2013.

Alvarado, M. J. and Prinn, R. G.: Formation of ozone and growth of aerosols in young smoke plumes from biomass burning: 1. Lagrangian parcel studies, J. Geophys. Res., 114, D09306, doi:10.1029/2008JD011144, 2009.

Alvarado, M. J., Wang, C., and Prinn, R. G.: Formation of ozone and growth of aerosols in young smoke plumes from biomass burning: 2.Three-dimensional Eulerian studies, J. Geophys. Res., 114, D09307, doi:10.1029/2008JD011186, 2009.

Alvarado, M. J., Logan, J. A., Mao, J., Apel, E., Riemer, D., Blake, D., Cohen, R. C., Min, K.-E., Perring, A. E., Browne, E. C., Wooldridge, P. J., Diskin, G. S., Sachse, G. W., Fuelberg, H., Sessions, W. R., Harrigan, D. L., Huey, G., Liao, J., Case-Hanks, A., Jimenez, J. L., Cubison, M. J., Vay, S. A., Weinheimer, A. J., Knapp, D. J., Montzka, D. D., Flocke, F. M., Pollack, I. B., Wennberg, P. O., Kurten, A., Crounse, J., Clair, J. M. St., Wisthaler, A., Mikoviny, T., Yantosca, R. M., Carouge, C. C., and Le Sager, P.: Nitrogen oxides and PAN in plumes from boreal fires during ARCTAS-B and their impact on ozone: an integrated analysis of aircraft and satellite observations, Atmos. Chem. Phys., 10, 9739-9760, doi:10.5194/acp10-9739-2010, 2010.

Alvarado, M. J., Yokelson, R. J., Akagi, S. A., Burling, I. R., Fischer, E., McMeeking, G. R., Travis, K., Craven, J. S., Seinfeld, J. H., Taylor, J. W., Coe, H., Urbanski, S. P., Wold, C. E., and Weise, D. R.: Lagrangian photochemical modeling of ozone formation and aerosol evolution in biomass burning plumes: toward a sub-grid scale parameterization, 12th Annual CMAS Conference, Chapel Hill, NC, 28-30 October 2013, 1-6, 2013.

Andreae, M. O. and Merlet, P.: Emission of trace gases and aerosols from biomass burning, Global Biogeochem. Cy., 15, 955-966, doi:10.1029/2000GB001382, 2001.

Andreae, M. O., Artaxo, P., Fischer, H., Freitas, S. R., Grégoire, J.-M., Hansel, A., Hoor, P., Kormann, R., Krejci, R., Lange, L., Lelieveld, J., Lindinger, W., Longo, K., Peters, W., de Reus, M., Scheeren, B., Silvia Dias, M. A. F., Ström, J., van Velthoven, P. F. J., and Williams, J.: Transport of biomass burning smoke to the upper troposphere by deep convection in the equatorial region, Geophys. Res. Lett., 28, 951-954, doi:10.1029/2000GL012391, 2001.

Atkinson, R., Aschmann, S. M., and Arey, J.: Reactions of $\mathrm{OH}$ and $\mathrm{NO}_{3}$ radicals with phenol, cresols, and 2nitrophenol at 296 \pm 2 K, Environ. Sci. Technol., 26, 1397-1403, doi:10.1021/es00031a018, 1992.

Azeez, A. M., Meier, D., and Odermatt, J.: Temperature dependence of fast pyrolysis volatile products from European and African biomasses, J. Anal. Appl. Pyrolysis, 90, 81-92, doi:10.1016/j.jaap.2010.11.005, 2011.

Barnes, I., Solignac, G., Mellouki, A., and Becker, K. H.: Aspects of the atmospheric chemistry of amides, Chem. Phys. Chem., 11, 3844-3857, doi:10.1002/cphc.201000374, 2010. 
Berndt, T., Böge, O., and Rolle, W.: Products of the gas-phase reactions of $\mathrm{NO}_{3}$ radicals with furan and tetramethylfuran, Environ. Sci. Technol., 31, 1157-1162, 1997.

Bierbach, A., Barnes, I., Becker, K. H., and Wiesen, E.: Atmospheric chemistry of unsaturated carbonyls: butenedial, 4-oxo2-pentenal, 3-hexene-2,5-dione, maleic anhydride, 3H-furan-2one, and 5-methyl-3H-furan-2-one, Environ. Sci. Technol., 28, 715-729, doi:10.1021/es00053a028, 1994.

Bierbach, A., Barnes, I., and Becker, K. H.: Product and kinetic study of the $\mathrm{OH}$-initiated gas-phase oxidation of furan, 2methylfuran, and furanaldehydes at $300 \mathrm{~K}$, Atmos. Environ., 29, 2651-2660, doi:10.1016/1352-2310(95)00096-H, 1995.

Bocchini, P., Galletti, G. C., Camarero, S., and Martinez, A. T.: Absolute quantitation of lignin pyrolysis products using an internal standard, J. Chromatogr. A, 773, 227-232, doi:10.1016/S00219673(97)00114-3, 1997

Bond, T. C., Streets, D. G., Yarber, K. F., Nelson, S. M., Woo, J.H., and Klimont, Z.: A technology-based global inventory of black and organic carbon emissions from combustion, J. Geophys. Res., 109, D14203, doi:10.1029/2003JD003697, 2004.

Bond, T. C., Doherty, S. J., Fahey, D. W., Forster, P. M., Berntsen, T., DeAngelo, B. J., Flanner, M. G., Ghan, S., Kärcher, B., Koch, D., Kinne, S., Kondo, Y., Quinn, P. K., Sarofim, M. C., Schultz, M. G., Schulz, M., Venkataraman, C., Zhang, H., Zhang, S., Bellouin, N., Guttikunda, S. K., Hopke, P. K., Jacobson, M. Z., Kaiser, J. W., Klimont, Z., Lohmann, U., Schwarz, J. P., Shindell, D., Storelvmo, T., Warren, S. G., and Zender, C. S.: Bounding the role of black carbon in the climate system: a scientific assessment, J. Geophys. Res., 118, 5380-5552, doi:10.1002/jgrd.50171, 2013.

Burling, I. R., Yokelson, R. J., Griffith, D. W. T., Johnson, T. J., Veres, P., Roberts, J. M., Warneke, C., Urbanski, S. P., Reardon, J., Weise, D. R., Hao, W. M., and de Gouw, J.: Laboratory measurements of trace gas emissions from biomass burning of fuel types from the southeastern and southwestern United States, Atmos. Chem. Phys., 10, 11115-11130, doi:10.5194/acp10-11115-2010, 2010.

Cabañas, B., Villanueva, F., Martin, P., Baeza, M. T., Salgado, S., and Jiménez, E.: Study of reaction processes of furan and some furan derivatives initiated by $\mathrm{Cl}$ atoms, Atmos. Environ., 39, 1935-1944, doi:10.1016/j.atmosenv.2004.12.013, 2005.

Chan, A. W. H., Kautzman, K. E., Chhabra, P. S., Surratt, J. D., Chan, M. N., Crounse, J. D., Kürten, A., Wennberg, P. O., Flagan, R. C., and Seinfeld, J. H.: Secondary organic aerosol formation from photooxidation of naphthalene and alkylnaphthalenes: implications for oxidation of intermediate volatility organic compounds (IVOCs), Atmos. Chem. Phys., 9, 3049-3060, doi:10.5194/acp-9-3049-2009, 2009.

Chhabra, P. S., Flagan, R. C., and Seinfeld, J. H.: Elemental analysis of chamber organic aerosol using an aerodyne high-resolution aerosol mass spectrometer, Atmos. Chem. Phys., 10, 4111-4131, doi:10.5194/acp-10-4111-2010, 2010.

Chhabra, P. S., Ng, N. L., Canagaratna, M. R., Corrigan, A. L., Russell, L. M., Worsnop, D. R., Flagan, R. C., and Seinfeld, J. H.: Elemental composition and oxidation of chamber organic aerosol, Atmos. Chem. Phys., 11, 8827-8845, doi:10.5194/acp-11-88272011, 2011.

Christian, T., Kleiss, B., Yokelson, R. J., Holzinger, R., Crutzen, P. J., Hao, W. M., Saharjo, B. H., and Ward, D. E.: Com- prehensive laboratory measurements of biomass burning emissions: 1. Emissions from Indonesian, African, and other fuels, J Geophys. Res., 108, 4719, doi:10.1029/2003JD003704, 2003.

Christian, T. J., Kleiss, B., Yokelson, R. J., Holzinger, R., Crutzen, P. J., Hao, W. M., Shirai, T., and Blake, D. R.: Comprehensive laboratory measurements of biomass burning emissions: 2. First intercomparison of open path FTIR, PTR-MS, GC-MS/FID/ECD, J. Geophys. Res., 109, D02311, doi:10.1029/2003JD003874, 2004.

Coeur-Tourneur, C., Cassez, A., and Wenger, J. C.: Rate coefficients for the gas-phase reaction of hydroxyl radicals with 2-methoxyphenol (guaiacol) and related compounds, J. Phys. Chem., 114, 11645-11650, doi:10.1021/jp1071023, 2010.

Crutzen, P. J. and Andreae, M. O.: Biomass burning in the tropics: impact on atmospheric chemistry and biogeochemical cycles, Science, 250, 1669-1678, doi:10.1126/science.250.4988.1669, 1990.

de Gouw, J. A., Warneke, C., Parrish, D. D., Holloway, J. S., Trainer, M., and Fehsenfeld, F. C.: Emission sources and ocean uptake of acetonitrile $\left(\mathrm{CH}_{3} \mathrm{CN}\right)$ in the atmosphere, J. Geophys. Res., 108, 4329, doi:10.1029/2002JD002897, 2003.

Desyaterik, Y., Sun, Y., Shen, X., Lee, T., Wang, X., Wang, T., and Collet Jr., J. L.: Speciation of "brown" carbon in cloud water impacted by agricultural biomass burning in eastern China, J. Geophys. Res. Atmos., 118, 7389-7399, doi:10.1002/jgrd.50561, 2013.

Dong, J. and DeBusk, S. M.: GC-MS analysis of hydrogen sulfide, carbonyl sulfide, methanethiol, carbon disulfide, methyl thicyanate and methyl disulfide in mainstream vapor phase cigarette smoke, Chromatographia, 71, 259-265, doi:10.1365/s10337009-1434-z, 2010.

Fisseha, R., Dommen, J., Sax, M., Paulsen, D., Kalberer, M., Maurer, R., Hofler, F., Weingartner, E., and Baltensperger, U.: Identification of organic acids in secondary organic aerosol and the corresponding gas phase from chamber experiments, Anal. Chem., 76, 6535-6540, doi:10.1021/Ac048975f, 2004.

Friedli, H. R., Atlas, E., Stroud, V. R., Giovanni, L., Campos, T., and Radke, L. F.: Volatile organic trace gases emitted from North American wildfires, Global Biogeochem. Cy., 15, 435452, doi:10.1029/2000GB001328, 2001.

Ge, X., Wexler, A. S., and Clegg, S. L.: Amospheric amines - Part I. A review, Atmos. Environ., 45, 524-546, doi:10.1016/j.atmosenv.2010.10.012, 2011.

Geron, C. and Hays, M.: Air emissions from organic soil burning on the coastal plain of North Carolina, Atmos. Environ., 64, 192 199, doi:10.1016/j.atmosenv.2012.09.065, 2013.

Gomez Alvarez, E. G., Borras, E., Viidanoja, J., and Hjorth, J.: Unsaturated dicarbonyl products from the $\mathrm{OH}$-initiated photooxidation of furan, 2-methylfuran and 3-methylfuran, Atmos. Environ, 43, 1603-1612, doi:10.1016/j.atmosenv.2008.12.019, 2009.

Goode, J. G., Yokelson, R. J., Susott, R. A., and Ward, D. E.: Trace gas emissions from laboratory biomass fires measured by Fourier transform infrared spectroscopy: fires in grass and surface fuels, J. Geophys. Res., 104, 21237-21245, doi:10.1029/1999JD900360, 1999.

Graus, M., Muller, M., and Hansel, A.: High Resolution PTR-TOF: quantification and formula confirmation of VOC 
in real time, J. Am. Soc. Mass. Spectr., 21, 1037-1044, doi:10.1016/j.jasms.2010.02.006, 2010.

Greenberg, J. P., Friedli, H., Guenther, A. B., Hanson, D., Harley, P., and Karl, T.: Volatile organic emissions from the distillation and pyrolysis of vegetation, Atmos. Chem. Phys., 6, 81-91, doi:10.5194/acp-6-81-2006, 2006.

Grieshop, A. P., Logue, J. M., Donahue, N. M., and Robinson, A. L.: Laboratory investigation of photochemical oxidation of organic aerosol from wood fires 1: measurement and simulation of organic aerosol evolution, Atmos. Chem. Phys., 9, 1263-1277, doi:10.5194/acp-9-1263-2009, 2009.

Griffith, D. W. T.: Synthetic calibration and quantitative analysis of gas phase infrared spectra, Appl. Spectrosc., 50, 59-70, 1996.

Harrison, M. A. J., Barra, S., Borghesi, D., Vione, D., Arsene, C., and Olariu, R. L.: Nitrated phenols in the atmosphere: a review, Atmos. Environ., 39, 231-248, doi:10.1016/j.atmosenv.2004.09.044, 2005.

Hawthorne, S. B., Krieger, M. S., Miller, D. J., and Mathiason, M. B.: Collection and quantitation of methoxylated phenol tracers for atmospheric-pollution from residential wood stoves, Environ. Sci. Technol., 23, 470-475, doi:10.1021/es00181a013, 1989.

Hawthorne, S. B., Miller, D. J., Langenfeld, J. J., and Krieger, M. S.: PM-10 High-volume collection and quantitation of semivolatile and nonvolatile phenols, methoxylated phenols, alkanes, and polycyclic aromatic-hydrocarbons from winter urban air and their relationship to wood smoke emissions, Environ. Sci. Technol., 26, 2251-2262, doi:10.1021/es00035a026, 1992.

Hatch, L. E., Luo, W., Pankow, J. F., Yokelson, R. J., Stockwell, C. E., and Barsanti, K. C.: Identification and quantification of gaseous organic compounds emitted from biomass burning using two-dimensional gas chromatography/time-of-flight mass spectrometry, Atmos. Chem. Phys. Discuss., 14, 23237-23307, doi:10.5194/acpd-14-23237-2014, 2014.

Heigenmoser, A., Liebner, F., Windeisen, E., and Richter, K.: Investigation of thermally treated beech (Fagus sylvatica) and spruce (Picea abies) by means of multifunctional analytical pyrolysis-GC/MS, J. Anal. Appl. Pyrol., 100, 117-126, doi:10.1016/j.jaap.2012.12.005, 2013.

Hennigan, C. J., Miracolo, M. A., Engelhart, G. J., May, A. A., Presto, A. A., Lee, T., Sullivan, A. P., McMeeking, G. R., Coe, H., Wold, C. E., Hao, W.-M., Gilman, J. B., Kuster, W. C., de Gouw, J., Schichtel, B. A., Collett Jr., J. L., Kreidenweis, S. M., and Robinson, A. L.: Chemical and physical transformations of organic aerosol from the photo-oxidation of open biomass burning emissions in an environmental chamber, Atmos. Chem. Phys., 11, 7669-7686, doi:10.5194/acp-11-76692011, 2011.

Henze, D. K., Seinfeld, J. H., Ng, N. L., Kroll, J. H., Fu, T.-M., Jacob, D. J., and Heald, C. L.: Global modeling of secondary organic aerosol formation from aromatic hydrocarbons: highvs. low-yield pathways, Atmos. Chem. Phys., 8, 2405-2420, doi:10.5194/acp-8-2405-2008, 2008.

Hildebrandt, L., Donahue, N. M., and Pandis, S. N.: High formation of secondary organic aerosol from the photo-oxidation of toluene, Atmos. Chem. Phys., 9, 2973-2986, doi:10.5194/acp-92973-2009, 2009.

Hinkel, M., Reischl, A., Schramm, K.-W., Trautner, F., Reissinger, M., and Hutzinger, O.: Concentration levels of nitrated phenols in conifer needles, Chemosphere, 18, 24332439, 1989.

Holzinger, R., Warneke, C., Hansel, A., Jordan, A., Lindinger, W., Scharffe, D. H., Schade, G., and Crutzen, P. J.: Biomass burning as a source of formaldehyde, acetaldehyde, methanol, acetone, acetonitrile, and hydrogen cyanide, Geophys. Res. Lett., 26, 1161-1164, doi:10.1029/1999GL900156, 1999.

Iinuma, Y., Böge, O., Gräfe, R., and Herrmann, H.: Methylnitrocatechols: atmospheric tracer compounds for biomass burning secondary organic aerosols, Environ. Sci. Technol., 44, 8453-8459, doi:10.1021/es102938a, 2010.

Im, Y., Jang, M., and Beardsley, R. L.: Simulation of aromatic SOA formation using the lumping model integrated with explicit gas-phase kinetic mechanisms and aerosol-phase reactions, Atmos. Chem. Phys., 14, 4013-4027, doi:10.5194/acp-14-4013$2014,2014$.

Ingemarsson, A., Nilsson, U., Nilsson, M., Pederson, J. R., and Olsson, J. O.: Slow pyrolysis of spruce and pine samples studied with GC/MS and GC/FTIR/FID, Chemosphere, 36, 2879-2889, doi:10.1016/S0045-6535(97)10245-4, 1998.

Jetter, J., Zhao, Y., Smith, K. R., Khan, B., Yelverton, T., DeCarlo, P., and Hays, M. D.: Pollutant emissions and energy efficiency under controlled conditions for household biomass cookstoves and implications for metrics useful in setting international test standards, Environ. Sci. Technol., 46, 10827-10834, doi:10.1021/es301693f, 2012.

Jiang, G., Nowakowski, D. J., and Bridgwater, A. V.: Effect of the temperature on the composition of lignin pyrolysis products, Energ. Fuel., 24, 4470-4475, doi:10.1021/ef100363c, 2010.

Jordan, A., Haidacher, S., Hanel, G., Hartungen, E., Märk, L., Seehauser, H., Schottkowsky, R., Sulzer, P., and Märk, T. D.: A high resolution and high sensitivity proton-transfer-reaction time-offlight mass spectrometer (PTR-TOF-MS), Int. J. Mass Spectrom., 286, 122-128, doi:10.1016/j.ijms.2009.07.005, 2009.

Jordan, T. B. and Seen, A. J.: Effect of airflow setting on the organic composition of woodheater emissions, Environ. Sci. Technol., 39, 3601-3610, doi:10.1021/es0487628, 2005.

Karl, T. G., Christian, T. J., Yokelson, R. J., Artaxo, P., Hao, W. M., and Guenther, A.: The Tropical Forest and Fire Emissions Experiment: method evaluation of volatile organic compound emissions measured by PTR-MS, FTIR, and GC from tropical biomass burning, Atmos. Chem. Phys., 7, 5883-5897, doi:10.5194/acp-7-5883-2007, 2007.

Kerminen, V. M., Lihavainen, H., Komppula, M., Viisanen, Y., and Kulmala, M.: Direct observational evidence linking atmospheric aerosol formation and cloud droplet activation, Geophys. Res. Lett., 32, L14803, doi:10.1029/2005g1023130, 2005.

Kessel, S., Auld, J., Crowley, J., Horowitz, A., Sander, R., Tucceri, M., Veres, P., and Williams, J.: Measurement of carbon suboxide $\left(\mathrm{C}_{3} \mathrm{O}_{2}\right)$ with PTR-TOF-MS - atmospheric sources and sinks, 6th International Conference on proton transfer reaction mass spectrometry and its applications, University of Innsbruck, 3-8 February 2013, 190-191, 2013.

Kirkby, J., Curtius, J., Almeida, J., Dunne, E., Duplissy, J., Ehrhart, S., Franchin, A., Gagné, S., Ickes, L., Kürten, A., Kupc, A., Metzger, A., Riccobono, F., Rondo, L., Schobesberger, S., Tsagkogeorgas, G., Wimmer, D., Amorim, A., Bianchi, F., Breitenlechner, M., David, A., Dommen, J., Downard, A., Ehn, M., Flagan, R. C., Haider, S., Hansel, A., 
Hauser, D., Jud, W., Junninen, H., Kreissl, F., Kvashin, A., Laaksonen, A., Lehtipalo, K., Lima, J., Lovejoy, E. R., Makhmutov, V., Mathot, S., Mikkilä, J., Minginette, P., Mogo, S., Nieminen, T., Onnela, A., Pereira, P., Petäjä, T., Schnitzhofer, R., Seinfeld, J. H., Sipilä, M., Stozhkov, Y., Stratmann, F., Tomé, A., Vanhanen, J., Viisanen, Y., Vrtala, A., Wagner, P. E., Walther, H., Weingartner, E., Wex, H., Winkler, P. M., Carslaw, K. S., Worsnop, D. R., Baltensperger, U., and Kulmala, M.: Role of sulphuric acid, ammonia and galactic cosmic rays in atmospheric aerosol nucleation, Nature, 476, 429-433, 2011.

Kitanovski, Z., Grgiæ, I., Yasmeen, F., Claeys, M., and Èusak, A.: Development of a liquid chromatographic method based on ultraviolet-visible and electrospray ionization mass spectrometric detection for the identification of nitrocatechols and related tracers in biomass burning atmospheric organic aerosol, Rapid Commun. Mass Sp., 26, 793-804, doi:10.1002/rcm.6170, 2012.

Kudo, S., Tanimoto, H., Inomata, S., Saito, S., Pan, X., Kanaya, Y., Taketani, F., Wang, Z., Chen, H., Dong, H., Zhang, M., and Yamaji, K.: Emissions of nonmethane volatile organic compounds from open crop residue burning in the Yangtze River Delta region, China, J. Geophys. Res. Atmos., 119, 7684-7698, doi:10.1002/2013JD021044, 2014.

Laaksonen, A., Hamed, A., Joutsensaari, J., Hiltunen, L., Cavalli, F., Junkermann, W., Asmi, A., Fuzzi, S., and Facchini, M. C.: Cloud condensation nucleus production from nucleation events at a highly polluted region, Geophys. Res. Lett., 32, L06812, doi:10.1029/2004g1022092, 2005.

Lauraguais, A., Coeur-Tourneur, C., Cassez, A., Deboudt, K., Fourmentin, M., and Choël, M.: Atmospheric reactivity of hydroxyl radicals with guaiacol (2-methoxyphenol), a biomass burning emitted compound: secondary organic aerosol formation and gas-phase oxidation products, Atmos. Environ., 86, 155-163, doi:10.1016/j.atmosenv.2013.11.074, 2014.

Li, Q., Steele, P. H., Yu, F., Mitchell, B., and Hassan, E.B. M.: Pyrolytic spray increases levoglucosan production during fast pyrolysis, J. Anal. Appl. Pyrol., 100, 33-40, doi:10.1016/j.jaap.2012.11.013, 2013.

Liu, Y., Shi, Q., Zhang, Y., He, Y., Chung, K. H., Zhao, S., and $\mathrm{Xu}, \mathrm{C}$ : Characterization of red pine pyrolysis biooil by gas chromatography-mass spectrometry and negativeion electrospray ionization fourier transform ion cyclotron resonance mass spectrometry, Energ. Fuel., 26, 4532-4539, doi:10.1021/ef300501t, 2012.

Lobert, J. M., Scharffe, D. H., Hao, W. M., Kuhlbusch, T. A., Seuwen, R., Warneck, P., and Crutzen, P. J.: Experimental evaluation of biomass burning emissions: nitrogen and carbon containing compounds, in: Global Biomass Burning: Atmospheric, Climatic, and Biospheric Implications, edited by: Levine, J. S., MIT Press, Cambridge, 289-304, 1991.

Ma, Y. and Hays, M. D.: Thermal extraction-two-dimensional gas chromatography-mass spectrometry with heart-cutting for nitrogen heterocyclics in biomass burning aerosols, J. Chromatogr. A, 1200, 228-234, doi:10.1016/j.chroma.2008.05.078, 2008.

Mason, S. A., Trentmann, J., Winterrath, T., Yokelson, R. J., Christian, T. J., Carlson, L. J., Warner, T. R., Wolfe, L. C., and Andreae, M. O.: Intercomparison of two box models of the chemical evolution in biomass burning smoke plumes, J. Atmos. Chem., 55, 273-297, doi:10.1007/s10874-006-9039-5, 2006.
Meinardi, S., Simpson, I. J., Blake, N. J., Blake, D. R., and Rowland, F. S.: Dimethyl disulfide (DMDS) and dimethyl sulfide (DMS) emissions from biomass burning in Australia, Geophys. Res. Lett., 30, 1454, doi:10.1029/2003GL016967, 2003.

Mohr, C., Lopez-Hilfiker, F. D., Zotter, P., Prévôt, A. S. H., Xu, L., Ng, N. L., Herndon, S. C., Williams, L. R., Franklin, J. P., Zahniser, M. S., Worsnop, D. R., Knighton, W. B., Aiken, A. C., Gorkowski, K. J., Dubey, M. K., Allan, J. D., and Thornton, J. A.: Contribution of nitrated phenols to wood burning brown carbon light absorption in Detling, United Kingdom during winter time, Environ. Sci. Technol., 47, 6316-6324, doi:10.1021/es400683v, 2013.

Müller, M., Graus, M., Ruuskanen, T. M., Schnitzhofer, R., Bamberger, I., Kaser, L., Titzmann, T., Hörtnagl, L., Wohlfahrt, G., Karl, T., and Hansel, A.: First eddy covariance flux measurements by PTR-TOF, Atmos. Meas. Tech., 3, 387-395, doi:10.5194/amt-3-387-2010, 2010.

Müller, M., George, C., and D'Anna, B.: Enhanced spectral analysis of C-TOF aerosol mass spectrometer data: iterative residual analysis and cumulative peak fitting, Int. J. Mass Spectrom., 306, 1-8, doi:10.1016/j.ijms.2011.04.007, 2011.

Müller, M., Mikoviny, T., Jud, W., D’Anna, B., and Wisthaler, A.: A new software tool for the analysis of high resolution PTRTOF mass spectra, Chemometr. Intell. Lab., 127, 158-165, doi:10.1016/j.chemolab.2013.06.011, 2013.

Na, K., Song, C., and Cocker III, D. R.: Formation of secondary organic aerosol from the reaction of styrene with ozone in the presence and absence of ammonia and water, Atmos. Environ., 40, 1889-1900, doi:10.1016/j.atmosenv.2005.10.063, 2006.

Natangelo, M., Mangiapan, S., Bagnati, R., Benfenati, E., and Fanelli, R.: Increased concentrations of nitrophenols in leaves from a damaged forestal site, Chemosphere, 38, 1495-1503, doi:10.1016/S0045-6535(98)00370-1, 1999.

Ng, N. L., Kroll, J. H., Chan, A. W. H., Chhabra, P. S., Flagan, R. C., and Seinfeld, J. H.: Secondary organic aerosol formation from $m$-xylene, toluene, and benzene, Atmos. Chem. Phys., 7, 39093922, doi:10.5194/acp-7-3909-2007, 2007.

Novakov, T. and Penner, J. E.: Large contribution of organic aerosols to cloud-condensation-nuclei concentrations, Nature, 365, 823-826, 1993.

Olariu, R. I., Klotz, B., Barnes, I., Becker, K. H., and Mocanu, R.: FT-IR study of the ring-retaining products from the reaction of $\mathrm{OH}$ radicals with phenol, $o-, m-$, and $p$-cresol, Atmos. Environ., 36, 3685-3697, doi:10.1016/S1352-2310(02)00202-9, 2002.

Page, S. E., Siegert, F., Rieley, J. O., Boehm, H. D. V., Jaya, A., and Limin, S.: The amount of carbon released from peat and forest fires in Indonesia during 1997, Nature, 420, 61-65, doi:10.1038/nature01131, 2002.

Phousongphouang, P. T. and Arey, J.: Rate constants for the gas-phase reactions of a series of alkylnaphthalenes with the OH radical, Environ. Sci. Technol., 36, 1947-1952, doi:10.1021/es011434c, 2002.

Pittman Jr., C. U., Mohan, D., Eseyin, A., Li, Q., Ingram, L., Hassan, E.-B. M., Mitchell, B., Guo, H., and Steele, P. H.: Characterization of bio-oils produced from fast pyrolysis of corn stalks in an auger reactor, Energ. Fuel., 26, 3816-3825, doi:10.1021/ef3003922, 2012.

Rehbein, P. J. G., Jeong, C.-H. J., McGuire, M. L., Yao, X., Corbin, J. C., and Evans, G. J.: Cloud and fog processing en- 
hanced gas-to-particle partitioning of trimethylamine, Environ. Sci. Technol., 45, 4346-4352, doi:10.1021/es1042113, 2011.

Reid, J. S., Hobbs, P. V., Ferek, R. J., Martins, J. V., Blake, D. R., Dunlap, M. R., and Liousse, C.: Physical, chemical, and radiative characteristics of the smoke dominated regional hazes over Brazil, J. Geophys. Res., 103, 32059-32080, doi:10.1029/98JD00458, 1998.

Rippen, G., Zietz, E., Frank, R., Knacker, T., and Klöpffer, W.: Do airborne nitrophenols contribute to forest decline?, Environ. Technol. Lett., 8, 475-482, doi:10.1080/09593338709384508, 1987.

Schade, G. W. and Crutzen, P. J.: Emission of aliphatic amines from animal husbandry and their reactions: potential source of $\mathrm{N}_{2} \mathrm{O}$ and $\mathrm{HCN}$, J. Atmos. Chem., 22, 319-346, doi:10.1007/BF00696641, 1995.

Shafizadeh, F.: Introduction to pyrolysis of biomass, J. Anal. Appl. Pyrol., 3, 283-305, doi:10.1016/0165-2370(82)80017-X, 1982.

Shon, Z. and Kim, K.: Photochemical oxidation of reduced sulfur compounds in an urban location based on short time monitoring data, Chemosphere, 63, 1859-1869, doi:10.1016/j.chemosphere.2005.10.021, 2006.

Simmleit, N. and Schulten, H.-S.: Thermal degradation products of spruce needles, Chemosphere, 18, 1855-1869, doi:10.1016/0045-6535(89)90469-4, 1989.

Simoneit, B. R. T., Rogge, W. F., Mazurek, M. A., Standley, L. J., Hildemann, L. M., and Cass, G. R.: Lignin pyrolysis products, lignans, and resin acids as specific tracers of plant classes in emissions from biomass combustion, Environ. Sci. Technol., 27, 2533-2541, doi:10.1021/es00048a034, 1993.

Simpson, I. J., Akagi, S. K., Barletta, B., Blake, N. J., Choi, Y., Diskin, G. S., Fried, A., Fuelberg, H. E., Meinardi, S., Rowland, F. S., Vay, S. A., Weinheimer, A. J., Wennberg, P. O., Wiebring, P., Wisthaler, A., Yang, M., Yokelson, R. J., and Blake, D. R.: Boreal forest fire emissions in fresh Canadian smoke plumes: $\mathrm{C}_{1}-\mathrm{C}_{10}$ volatile organic compounds (VOCs), $\mathrm{CO}_{2}, \mathrm{CO}, \mathrm{NO}_{2}, \mathrm{NO}, \mathrm{HCN}$ and $\mathrm{CH}_{3} \mathrm{CN}$, Atmos. Chem. Phys., 11, 6445-6463, doi:10.5194/acp-11-6445-2011, 2011.

Sjöström, E.: Wood Chemistry: Fundamentals and Applications, 2nd edn., Academic Press, San Diego, USA, 1993.

Smith, J. N., Dunn, M. J., VanReken, T. M., Iida, K., Stolzenburg, M. R., McMurry, P. H., and Huey, L. G.: Chemical composition of atmospheric nanoparticles formed from nucleation in Tecamac, Mexico: evidence for an important role for organic species in nanoparticle growth, Geophys. Res. Lett., 35, L04808, doi:10.1029/2007g1032523, 2008.

Song, C., Na, K., Warren, B., Malloy, Q., and Cocker, D. R.: Impact of propene on secondary organic aerosol formation from $m$-xylene, Environ. Sci. Technol., 41, 6990-6995, doi:10.1021/es062279a, 2007.

Sotiropoulou, R. E. P., Tagaris, E., Pilinis, C., Anttila, T., and Kulmala, M.: Modeling new particle formation during air pollution episodes: impacts on aerosol and cloud condensation nuclei, Aerosol Sci. Tech., 40, 557-572, doi:10.1080/02786820600714346, 2006.

St. Clair, J. M., Spencer, K. M., Beaver, M. R., Crounse, J. D., Paulot, F., and Wennberg, P. O.: Quantification of hydroxyacetone and glycolaldehyde using chemical ionization mass spectrometry, Atmos. Chem. Phys., 14, 4251-4262, doi:10.5194/acp14-4251-2014, 2014.
Stockwell, C. E., Yokelson, R. J., Kreidenweis, S. M., Robinson, A. L., DeMott, P. J., Sullivan, R. C., Reardon, J., Ryan, K. C., Griffith, D. W. T., and Stevens, L.: Trace gas emissions from combustion of peat, crop residue, biofuels, grasses, and other fuels: configuration and Fourier transform infrared (FTIR) component of the fourth Fire Lab at Missoula Experiment (FLAME-4), Atmos. Chem. Phys., 14, 9727-9754, doi:10.5194/acp-14-97272014, 2014.

Strollo, C. M. and Ziemann, P. J.: Products and mechanism of secondary organic aerosol formation from the reaction of 3methylfuran with $\mathrm{OH}$ radicals in the presence of $\mathrm{NO}_{\mathrm{x}}$, Atmos. Environ., 77, 534-543, doi:10.1016/j.atmosenv.2013.05.033, 2013.

Tkacik, D., Robinson, E., Ahern, A., Saleh, R., Veres, P., Stockwell, C., Simpson, I., Meinardi, S., Blake, D., Presto, A., Sullivan, R., Donahue, N., and Robinson, A.: A dual chamber enhancement method to quantify aerosol formation: biomass burning secondary organic aerosol, in preparation, 2014.

Toda, K., Obata, T., Obokin, V. A., Potemkin, V. L., Hirota, K., Takeuchi, M., Arita, S., Khodzher, T. V., and Grachev, M. A.: Atmospheric methanethiol emitted from a pulp and paper plant on the shore of Lake Baikal, Atmos. Environ., 44, 2427-2433, doi:10.1016/j.atmosenv.2010.03.037, 2010.

Trentmann, J., Andreae, M. O., and Graf, H.-F.: Chemical processes in a young biomass burning plume, J. Geophys. Res., 108, 4705, doi:10.1029/2003JD003732, 2003.

Trentmann, J., Yokelson, R. J., Hobbs, P. V., Winterrath, T., Christian, T. J., Andreae, M. O., and Mason, S. A.: An analysis of the chemical processes in the smoke plume from a savanna fire, J. Geophys. Res., 110, D12301, doi:10.1029/2004JD005628, 2005.

Vakkari, V., Kerminen, V.-M., Beukes, J. P., Tiitta, P., van Zyl, P. G., Josipovic, M., Venter, A. D., Jaars, K., Worsnop, D. R., Kulmala, M., and Laakso, L.: Rapid changes in biomass burning aerosols by atmospheric oxidation, Geophys. Res. Lett., 41, 2644-2651, doi:10.1002/2014GL059396, 2014.

Veres, P., Roberts, J. M., Burling, I. R., Warneke, C., de Gouw, J., and Yokelson, R. J.: Measurements of gas-phase inorganic and organic acids from biomass fires by negative-ion proton-transfer chemical-ionization mass spectrometry, J. Geophys. Res., 115, D23302, doi:10.1029/2010JD014033, 2010.

Villanueva, F., Barnes, I., Monedero, E., Salgado, S., Gómez, M. V., and Martin, P.: Primary product distribution from the Cl-atom initiated atmospheric degradation of furan: environmental implications, Atmos. Environ., 41, 8796-8810, doi:10.1016/j.atmosenv.2007.07.053, 2007.

Wagner, V., Jenkin, M. E., Saunders, S. M., Stanton, J., Wirtz, K, and Pilling, M. J.: Modelling of the photooxidation of toluene: conceptual ideas for validating detailed mechanisms, Atmos. Chem. Phys., 3, 89-106, doi:10.5194/acp-3-89-2003, 2003.

Ward, D. E. and Radke, L. F.: Emissions measurements from vegetation fires: a comparative evaluation of methods and results, in: Fire in the Environment: the Ecological, Atmospheric and Climatic Importance of Vegetation Fires, edited by: Crutzen, P. J. and Goldammer, J. G., John Wiley, New York, 53-76, 1993.

Warneke, C., Roberts, J. M., Veres, P., Gilman, J., Kuster, W. C., Burling, I., Yokelson, R. J., and de Gouw, J. A.: VOC identification and inter-comparison from laboratory biomass burning using PTR-MS and PIT-MS, Int. J. Mass Spectrom., 303, 6-14, doi:10.1016/j.ijms.2010.12.002, 2011. 
Wiedinmyer, C., Akagi, S. K., Yokelson, R. J., Emmons, L. K., AlSaadi, J. A., Orlando, J. J., and Soja, A. J.: The Fire INventory from NCAR (FINN): a high resolution global model to estimate the emissions from open burning, Geosci. Model Dev., 4, 625641, doi:10.5194/gmd-4-625-2011, 2011.

Williams, C. J. and Yakvitt, J. B.: Botanical composition of peat and degree of peat decomposition in three temperate peatlands, Ecoscience, 10, 85-95, 2003.

Yee, L. D., Kautzman, K. E., Loza, C. L., Schilling, K. A., Coggon, M. M., Chhabra, P. S., Chan, M. N., Chan, A. W. H., Hersey, S. P., Crounse, J. D., Wennberg, P. O., Flagan, R. C., and Seinfeld, J. H.: Secondary organic aerosol formation from biomass burning intermediates: phenol and methoxyphenols, Atmos. Chem. Phys., 13, 8019-8043, doi:10.5194/acp-13-80192013, 2013.

Yokelson, R. J., Griffith, D. W. T., and Ward, D. E.: Open path Fourier transform infrared studies of large-scale laboratory biomass fires, J. Geophys. Res., 101, 21067-21080, doi:10.1029/96JD01800, 1996.

Yokelson, R. J., Goode, J. G., Ward, D. E., Susott, R. A., Babbitt, R. E., Wade, D. D., Bertschi, I., Griffith, D. W. T., and Hao, W. M.: Emissions of formaldehyde, acetic acid, methanol, and other trace gases from biomass fires in North Carolina measured by airborne Fourier transform infrared spectroscopy, J. Geophys. Res., 104, 30109-30125, doi:10.1029/1999jd900817, 1999.

Yokelson, R. J., Karl, T., Artaxo, P., Blake, D. R., Christian, T. J., Griffith, D. W. T., Guenther, A., and Hao, W. M.: The Tropical Forest and Fire Emissions Experiment: overview and airborne fire emission factor measurements, Atmos. Chem. Phys., 7, 5175-5196, doi:10.5194/acp-7-5175-2007, 2007.
Yokelson, R. J., Crounse, J. D., DeCarlo, P. F., Karl, T., Urbanski, S., Atlas, E., Campos, T., Shinozuka, Y., Kapustin, V., Clarke, A. D., Weinheimer, A., Knapp, D. J., Montzka, D. D., Holloway, J., Weibring, P., Flocke, F., Zheng, W., Toohey, D., Wennberg, P. O., Wiedinmyer, C., Mauldin, L., Fried, A., Richter, D., Walega, J., Jimenez, J. L., Adachi, K., Buseck, P. R., Hall, S. R., and Shetter, R.: Emissions from biomass burning in the Yucatan, Atmos. Chem. Phys., 9, 5785-5812, doi:10.5194/acp-9-5785-2009, 2009.

Yokelson, R. J., Burling, I. R., Gilman, J. B., Warneke, C., Stockwell, C. E., de Gouw, J., Akagi, S. K., Urbanski, S. P., Veres, P., Roberts, J. M., Kuster, W. C., Reardon, J., Griffith, D. W. T., Johnson, T. J., Hosseini, S., Miller, J. W., Cocker III, D. R., Jung, H., and Weise, D. R.: Coupling field and laboratory measurements to estimate the emission factors of identified and unidentified trace gases for prescribed fires, Atmos. Chem. Phys., 13, 89-116, doi:10.5194/acp-13-89-2013, 2013.

$\mathrm{Yu}, \mathrm{F}$. and Luo, G.: Modeling of gaseous methylamines in the global atmosphere: impacts of oxidation and aerosol uptake, Atmos. Chem. Phys., 14, 12455-12464, doi:10.5194/acp-1412455-2014, 2014.

Zhang, X., Lin, Y.-H., Surratt, J. D., Zotter, P., and Weber, R. J.: Sources, composition and absorption Ångström exponent of light-absorbing organic components in aerosol extracts from the Los Angeles Basin, Environ. Sci. Technol., 47, 3685-3693, doi:10.1021/ES305047B, 2013.

Ziemann, P. J. and Atkinson, R.: Kinetics, products, and mechanisms of secondary organic aerosol formation, Chem. Soc. Rev., 41, 6582-6605, doi:10.1039/c2cs35122f, 2012. 